\title{
Mobile Phones and Attitudes Towards Women's Participation in Politics: Evidence from Africa
}

\author{
Carlotta Varriale, ${ }^{1}$ Luca Maria Pesando, ${ }^{2}$ Ridhi Kashyap, ${ }^{3}$ and \\ Valentina Rotondi ${ }^{3,41}$ \\ ${ }^{1}$ Department of Social and Political Sciences and Dondena Centre for Research on \\ Social Dynamics and Public Policy, Bocconi University \\ ${ }^{2}$ Department of Sociology and Centre on Population Dynamics, McGill University \\ ${ }^{3}$ Department of Sociology and Nuffield College, University of Oxford \\ ${ }^{4}$ Department of Business Economics, Health and Social Care, University of Applied Sciences \\ and Arts of Southern Switzerland and University of Oxford
}

*** Paper published in Sociology of Development (https://doi.org/10.1525/sod.2020.0039): Please cite that version $* * *$

\begin{abstract}
This study explores the relationship between technology adoption and attitudes towards gender equality in political representation by relying on diffusion theories coupled with frameworks of ideational change, social interaction, and world society. We examine whether the use of mobile phones shapes gender attitudes towards women's participation in politics by making it more widely accepted that women hold institutional roles. We do so by using micro-level data from the AfroBarometer, covering 36 African countries and adopting a multilevel modeling approach. Our results suggest that regular use of mobile phones is associated with more positive attitudes towards women's participation in politics. The significant relationship - robust to the use of instrumental variable (IV) techniques - is observed only among women. This finding strengthens the idea that technology adoption on the part of women, by improving connectivity and expanding access to information, may be a successful lever to raise women's status and promote societal well-being, ultimately contributing to achieving Sustainable Development Goal (SDG) 5 that seeks to "achieve gender equality and empower all women and girls." Concurrently, the lack of a significant relationship for men highlights an important yet often neglected issue: policies aimed at changing gender attitudes are often targeted towards women, but men's attitudes can be stickier than women's, thus requiring further attention.
\end{abstract}

Keywords: Women, Technology, Mobile Phones, Social Change, Politics, Africa, Gender, Attitudes, SDGs

${ }^{1}$ Corresponding author: valentina.rotondi@supsi.ch or valentina.rotondi@sociology.ox.ac.uk 
CARLOTTA VARRIALE (D)

Bocconi University, carlotta.varriale@phd.unibocconi.it

LUCA MARIA PESANDO D

McGill University, lucamaria.pesando@mcgill.ca

RIDHI KASHYAP

University of Oxford, ridhi.kashyap@nuffield.ox.ac.uk

VALENTINA ROTONDI (CORRESPONDING AUTHOR)

University of Applied Sciences and Arts of Southern Switzerland, valentina.rotondi@supsi.ch

\title{
Mobile Phones and Attitudes toward Women's Participation in Politics
}

Evidence from Africa

\begin{abstract}
This study explores the relationship between technology adoption and attitudes toward gender equality in political representation by relying on diffusion theories coupled with frameworks of ideational change, social interaction, and world society. We examine whether the use of mobile phones shapes gender attitudes toward women's participation in politics by making it more widely accepted that women hold institutional roles. We do so with micro-level data from the AfroBarometer, covering 36 African countries, and a multilevel modeling approach. Our results suggest that regular use of mobile phones is associated with more positive attitudes toward women's participation in politics. The significant relationship-robust to the use of instrumental variable techniques-is observed only among women. This finding strengthens the idea that technology adoption on the part of women, by improving connectivity and expanding access to information, may be a successful lever to raise women's status and promote societal well-being, ultimately contributing to achieving Sustainable Development Goal 5, which seeks to "achieve gender equality and empower all women and girls." Concurrently, the lack of a significant relationship for men highlights an important yet often neglected issue: policies aimed at changing gender attitudes are often targeted at women, but men's attitudes can be stickier than women's, thus requiring further efforts. KEYWORDS women, technology, mobile phones, social change, politics, Africa, gender attitudes, SDGs
\end{abstract}

WOMEN'S PARTICIPATION IN POLITICS and policymaking has the potential to improve outcomes for women, children, and societies as a whole (Beaman et al. 2012; Swiss, Fallon, and Burgos 2012). The positive impact of women's political representation has been acknowledged to such an extent that women's political empowerment has been deemed a high-priority issue for policymakers around the world. For instance, the UN includes women's representation at all levels of political leadership among its indicators of gender equality, and gender parity in political representation constitutes an essential element of Sustainable Development Goal 5 (SDG 5). ${ }^{1}$ Despite these recognitions,

Sociology of Development, pps. I-37, electronic ISSN: 2374-538X (C) 202I by the Regents of the University of California. All rights reserved. Please direct all requests for permission to photocopy or reproduce article content through the University of California Press's Reprints and Permissions web page, https://www.ucpress.edu/journals/ reprints-permissions. DOI: https://doi.org/I0.1525/sod.2020.0039 
women's representation in national legislatures remains low (around $25 \%$ in 2020) in sub-Saharan Africa and globally. ${ }^{2}$

Support for the inclusion of women in public institutions rests on two major arguments: equity and efficiency. On the one hand, the UN Charter of Human Rights, the Convention on the Elimination of All Forms of Discrimination against Women (1979), the Beijing Plan of Action, and many other international agreements represent a consensus on the right of women to be part of political decision-making across the globe (equity). On the other hand, increasing women's presence in political institutions, especially through higher shares of female participation in politics and policymaking roles, should lead to better representation of the interests and political preferences of women themselves (Tripp and Kang 2008). This enhanced female representation might in turn increase the attention paid to policies dealing with families and children (efficiency) (Reynolds I999). ${ }^{3}$

Recently, Gottlieb, Grossman, and Robinson (2018) investigated gender-based political differences and gender gaps in issue prioritization in 27 African countries. They observed diverging preferences between female and male respondents for policies related to public spending (e.g., on infrastructure), access to clean water, and poverty alleviation projects, with the latter two issues supported more among women than among men. ${ }^{4}$ Female representation and participation in politics tended to be lower in precisely those areas which showed the highest rates of gender policy-issue divergences-that is, those that would benefit the most from an increase in women's participation in politics.

Qualitative (Nelson and Chowdhury 1994; Rule and Zimmerman 1994) and quantitative studies (Inglehart and Norris 2003; Paxton and Kunovich 2003) highlight the importance of normative and ideological factors for explaining greater women's political representation. These include greater societal acceptance of ideas about women and men having the same right to be elected, and whether women can and should be able to hold institutional roles in the public sphere. In this respect, more gender-equitable access to information, media exposure highlighting women assuming different (including political) roles, and better connectivity and wider networks for civic participation can help facilitate greater awareness and promote cultural acceptance of women in politics.

Mobile technology can be one lever to promote more gender-balanced access to information and media, and connectivity to wider networks. Since the beginning of the new millennium, the diffusion of mobile phones across the world has been the key technological shift in the landscape of information, communication, and media technologies. The diffusion of mobile phones has occurred across different regions of the world, but particularly in some contexts, such as sub-Saharan Africa, the spread of mobile telephony has led to the establishment of the first wide-reaching telecommunications infrastructure, in contrast to the poor and often declining landline penetration throughout the continent (Aker and Mbiti 20Io). Mobile phones have also enabled the spread of the Internet in the region (GSMA 2020).

Research suggests that the impacts of mobile phones are likely to be larger in lowincome regions, where other types of infrastructure are poorer (Aker and Mbiti 20Io; Rotondi et al. 2020), but even within these regions, the impacts of access to mobile 
technology may be larger for more marginalized groups, such as women, who face greater barriers to accessing information, services, and networks (Rotondi et al. 2020). This potential is expressly acknowledged in Target $5 \mathrm{~B}$ of SDG 5, to enhance the use of enabling technology_information and communication technologies (ICTs) — as a way to promote female empowerment. ${ }^{5}$

Although the impacts of mobile phones on measures of economic and social development have been documented (e.g., Aker 20I0; Aker, Ksoll, and Lybbert 2012; Jack and Suri 2014; Rotondi et al. 2020; Suri and Jack 2016), to the best of our knowledge no study has examined the link between mobile-phone use and attitudes linked to gender equality, especially focusing on women's political representation and adopting a largescale empirical approach. This study seeks to address a piece of this puzzle by exploring whether the use of mobile phones shapes gender attitudes toward women's participation in politics by making it more widely accepted that women hold institutional roles. It also attempts to unpack for whom the associations operate, to the extent possible given the available data. We use micro-level data from the AfroBarometer, collected in 36 African countries in 2015. Building on ideational frameworks, world-society perspectives, and the "theory of conjunctural action" of Johnson-Hanks et al. (20II), we hypothesize that mobile phones can serve as crucial material elements - "objects"-acting through normative change to affect macro-level cultural scripts, which in turn shape gender-related schemas-unobserved mental maps through which we make sense of the external world.

Our results suggest that mobile-phone use is positively associated with the likelihood of holding the belief that women should have the same chances to be elected as men. However, the significant relationship-which is stable across specifications and robust to the use of instrumental variable techniques-is observed only among women, thus highlighting how technology adoption on the part of women can be a successful lever to raise women's status and promote societal well-being. Moreover, we show that neither mastering another language (such as English, French, or Arabic) nor discussing political matters with family and friends is a significant moderator in this relationship. Nonetheless, we find that mobile phones are more beneficial for women who are either unemployed or employed in non-wage occupations - that is, more vulnerable women.

Our findings strengthen the idea that investing in cheaper, equitable access, enabling independent ownership, and focusing on ICT skill development, especially among vulnerable women, is a promising way to leverage technology for sustainable development and global social change (including normative change) and, foremost, to attain SDG 5.

\section{BACKGROUND}

\section{Technology and Social Change}

The impact of different media technologies on social attitudes and behaviors has been a topic of significant interest among social scientists. Scholars have documented the impact of television on political (DellaVigna and Kaplan 2007; Durante, Pinotti, and Tesei 2019; Enikolopov, Petrova, Zhuravskaya 20II), demographic (Chong and La Ferrara 2009; Kearney and Levine 2015; La Ferrara, Chong, and Duryea 2012), and 
economic and social attitudes, norms, and behaviors (Bruni and Stanca 2006; Bursztyn and Cantoni 2016; Hyll and Schneider 2013; Jensen and Oster 2009; Olken 2009). Looking specifically at work on the impacts of television or other media on outcomes linked to gender attitudes, while several studies have found a positive association between media exposure and more gender-egalitarian attitudes, some have found opposite patterns, as well as cross-country heterogeneity. Jensen and Oster (2009) found that the introduction of cable television in India was positively linked with improvements in women's status and gender attitudes, with women reporting an increase in autonomy, a decrease in the acceptability of intimate partner violence (IPV), and a decrease in son preference. Similar results for decreased son preference with greater TV exposure were also found for India by Chatterjee and Pillai (2018). In a cross-national analysis of attitudes toward IPV by Pierotti (2013), in I4 out of 26 low- and middle-income countries (LMICs) TV, radio, or newspaper access at least once a week was associated with lower odds of accepting IPV, but it was not a significant predictor in Io countries. Focusing on sub-Saharan Africa and attitudes to IPV, Uthman, Lawoko, and Moradi (2009) and Lawoko (2006) both found that women with greater media (TV and radio) exposure reported less tolerance of IPV. On the other hand, Okenwa-Emegwa, Lawoko, and Jansson (2016) found that access to TV/radio was associated with higher odds of tolerating IPV among women in Nigeria-but, interestingly, lower odds for men. Similarly, Banerjee, La Ferrara, and Orozco (2019) found that an MTV edutainment series lowered acceptance of IPV among men in Nigeria, but not among women.

Looking into the new millennium, the rapid diffusion of ICTs, in particular mobile phones and the Internet, has been the major technological shift. The spread of these technologies has paved the way for the digital revolution, which has affected all parts of the world, as well as different domains of everyday life. Today, the estimated number of mobile subscriptions in the world is over 7 billion, and mobile diffusion has occurred even in the most remote regions (Rotondi et al. 2020). The diffusion of mobile phones has been linked to several social and economic development outcomes. Waverman, Meschi, and Fuss (2005) found that mobile phones have a positive impact on the economic development of LMICs. They documented that the GDP-per-capita growth of a low-income country with Io additional mobile phones per Ioo inhabitants between 1996 and 2003 was 0.59 percent higher than that of an otherwise identical country. Studies based on micro-level data have examined specific mechanisms, finding similarly positive economic impacts. Mobile phones have been found to improve efficiency in agricultural (Aker 20I0) and fish markets by providing better market information (Jensen 2007), to allow micro-entrepreneurs to expand business contacts (Donner 2006), and to facilitate financial transactions such as processing remittances and obtaining micro-credit (Talbot 2008).

As for social impacts, the sociological literature suggests that phones compress social time and space (Geser 2004; Green 2002). Using survey data from Taiwan, Wei and Lo (2006) argued that mobile phones strengthen users' family bonds, expand their psychological boundaries, and facilitate symbolic proximity to the people they call by streamlining communication. Phones are especially valuable to women, as they serve as a liberator 
(Frissen 2007; Rakow 1992) and can enable them to reconcile different social roles, such as being a parent and in the labor force (Madianou and Miller 20II). Evidence suggests that these emancipatory effects may differ across contexts. For instance, focusing on Japan, Dobashi (2005) found that mobile phones reinforce and reproduce the existing social roles of Japanese housewives rather than liberating or altering them. On the other hand, examining women's use of phones in a small-community setting in the United States, Rakow (1992) argued that phones mitigate women's fears and sense of isolation, loneliness, and boredom by helping them cope with confinement at home and physical separation from their own family members and friends-as also discussed by Pesando and Rotondi (2020) and Pesando (forthcoming). Not least, the potential of mobile phones may be even greater in light of the "community liberated" argument discussed by Wellman (1979), according to which people do not seek support in their immediate neighborhood but rather entertain a network of far-flung ties, often dispersed among multiple social networks. In such a context, mobile phones could improve opportunities to sustain ties with distant others and mobilize ties effectively in times of need.

The liberating effect of mobile phones is likely to be larger in communities where women's status is lower and women face higher communication and information barriers. Women in low-income countries tend to face high barriers when traveling long distances to visit family, friends, or potential business contacts. Hence, they have fewer opportunities to voice their concerns, viewpoints, ideas, or plans, and to form networks to, for instance, find jobs, start businesses, or participate in their communities. In these contexts, mobile phones may empower women by improving their access to social and economic services, as work by Suri and Jack (2016) has shown, and also boost access to information regarding their health and well-being and their ability to make independent decisions, as cross-national and regional empirical evidence from sub-Saharan Africa shows (Rotondi et al. 2020). Features unique to mobile phones as an ICT, such as portability, text messaging, and (in the case of Internet-enabled phones) data downloading, may also help women participate in the labor force by giving them more timely and accurate market information, access to services like mobile banking, and greater flexibility of communication and ability to connect with networks, including those outside their immediate kin. Besides, unlike desktop computers or laptops, mobile phones do not require sophisticated literacy or digital skills that many women in LMICs often lack (Fatehkia, Kashyap, and Weber 2018). Thus, direct access to phones may empower women by increasing opportunities for communication, enabling expanded networks and connectivity, and making information available.

Building on the theoretical model developed by Jensen and Oster (2009) in analyzing the impacts of TV, Lee (2009) examined the impact of mobile phones on the status of women in India, finding that mobile phones significantly decreased both men's and women's tolerance for domestic violence and increased women's autonomy in travel and economic independence. With their potential to reach multiple people and the opportunity to connect with wider networks beyond co-resident kin ties, mobile phones may open up new avenues for social learning, mutual-information exchange, and community engagement, thereby reshaping the traditional learning paths 
long recognized as drivers of gender-role changes (Bongaarts and Watkins I996; Montgomery and Casterline 1996).

Furthermore, access to "the life of others" through media content and social networking sites (e.g., Facebook) accessible through mobile Internet might provide alternative role models to those visible through routine social interactions and change the desirability and social acceptability of certain roles and behaviors, such as political roles. The potential direction of the "media effect," however, could depend on the specific content of media, which may not necessarily be liberalizing. For example, in their study on attitudes to IPV in Nigeria, Okenwa-Emegwa, Lawoko, and Jansson (2016) explain their finding of increased odds of accepting IPV among women with greater TV/radio exposure as being linked to content promoting gender stereotypes and traditional beliefs in Nigerian films and TV programming. A related result was found in Honduras, where listening to the radio one or more times per week was associated with greater IPV approval among men, while newspaper and television use showed no significant association (Forsyth and Ward 202I).

In contrast to television and radio, which often have a more national focus, mobile phones may enable exposure to media content that transcends national boundaries and thus promote exposure to less context-specific and more globalized and liberalized cultural scripts about women's roles in society. Following a world-society theoretical perspective, liberal individualistic principles predicated on principles of individual equalityand within these, ideals of gender equality - constitute world-society norms that acquired cultural authority throughout the second half of the twentieth century (Frank, Hardinge, and Wosick-Correa 2009; Meyer et al. 1997). In the African context, exposure to these global cultural scripts, which are likely to promote world-society norms, increasingly occurs through digital media available through mobile phones (Pew Research Centre 2015; Zayani 2015). Consistent with this idea, a recent empirical paper on Africa by Charles (2020) using two waves of the AfroBarometer showed that gender liberalism surrounding the belief that men and women should have equal rights is stronger among individuals who are more exposed to global culture via the Internet and mobile phone use. Global (or world) culture can be defined as a set of cultural scripts and liberal egalitarian principles of intrinsic human equality that are propagated by world-society elites and shape the worldwide view of how men and women should live and be educated (Meyer 20I0; Pierotti 2013).

While Charles's study examines gender equality broadly in terms of equal rights, it is a priori unclear whether exposure to global culture may also shift norms about women's political participation as a specific domain of gender equality. Research suggests that attitudes to different domains of gender equality can vary (Glas et al. 20I9; Price 20I4). For example, across the world, attitudes toward women in politics are more conservative than those toward women in education (Price 2014). One potential explanation for this is that the perceived conflict between women's family roles and political participation may be greater than with their participation in education (Glas 2019), suggesting that attitudes to women's political participation may be more resistant to change. 
This study seeks to complement the above literature by examining the link between the use of mobile phones and a specific domain of gender equality: the legitimacy of female representation in parliament. Greater mobile-phone use may increase the subjective legitimacy of female representation in the public sphere by expanding individual-but more significantly, women's-networks, improving information exchange through better-connected networks, and expanding access to more global media content and representation. Women's networks are expanded in such a way that access to communication that was previously restricted to either in-person social networks or unidirectional mass media such as radio or TV becomes widely, quickly, and cheaply available (Bongaarts and Watkins 1996; Montgomery and Casterline 1996). Recent qualitative evidence suggests that this is a reasonable association to expect. Abubakar and Dasuki (2018) found that that the use of WhatsApp in Nigeria enabled women to voice their opinions and political views more openly by joining, for instance, online forums created by women leaders, thereby also enabling greater civic participation. WhatsApp forums provided avenues for female leaders to share updates on programs and projects being executed by politicians. Another key use of WhatsApp groups mentioned by female respondents was to hold elected officers accountable for promises made during election campaigns. Other evidence from the African context also finds support for how SMS-based communication can amplify the participatory features of otherwise unidirectional media such as radio, creating new spaces for voice and public discussion around critical issues (Abreu Lopes and Srinivasan 2014). Research in the Balkans has highlighted that mobile phones-even through basic features such as quick connectivity and communication-enabled swift and efficient community participation and organizing around key political issues surrounding constitutional reform. They also enabled greater engagement among women who had previously been disengaged from politics (GSMA 20IO).

\section{Theoretical Perspectives}

Diffusion theories, coupled with frameworks of ideational change and social interaction, provide useful theoretical perspectives through which to understand the implications of mobile-phone diffusion for normative changes linked to gender roles and dynamics. These theories have been influential in explaining fertility decline in the sociodemographic literature (Bongaarts and Watkins 1996; Knodel and van de Walle 1979). Applied to fertility decline, these theories suggest that individuals, communities, and nation-states interact with each other, spreading information, ideas, and technology regarding contraception, fertility ideals, and family size. Diffused ideas and technologies are received and reinterpreted, gaining new meaning in different contexts and impelling or constraining actions pertaining to fertility choice. Research has stressed the important role information and mass media play in shaping beliefs regarding family limitation (Westoff and Koffman 20II), and empirical support for these pathways vis-à-vis radio, television, and mobile phones has been found (Billari, Rotondi, and Trinitapoli 2020; Jensen and Oster 2009; La Ferrara, Chong, and Duryea 2012). Theoretically, we anticipate that through the aforementioned mechanisms of increased access to 
communication and exchange, information, and globalized media content, mobile phones might be capable of spurring the diffusion of novel beliefs alongside the transformation and re-elaboration of gender ideologies, in line with a world-society discourse.

In more recent work, Johnson-Hanks et al. (20II) tried to unify theories of diffusion, ideational change, and social interaction in their theory of conjunctural action. It explains variation in fertility and family-and, by extension, gender-related outcomes-by considering the intersection of virtual and perceptible structures. The primary building blocks of the theory are "schemas" and "materials." Schemas are unobserved mental maps or scripts, defined as "ways of perceiving and acting through which we make sense of the world and motivate our actions." They are created and altered over time through interaction, perception, and comprehension in a pathdependent process. Schemas thus reflect the social, psychological, and physical environments in which individuals and populations are embedded. Materials are "the objects, performances, and organizations that sediment schemas in the perceptible world" (8). They instantiate schemas by introducing and enforcing them in the realm of social action. Structure is thus formed and reshaped by the interaction of existing schemas with newly introduced material elements.

In the context of macro-level changes in gender norms, individual schemas are affected by macro-structures (e.g., cultural scripts) that emerge and evolve at the community or the nation-state level. Communities are the domain of local culture, while nation-states are the domain of national culture and institution-building, so schemas ultimately reflect the symbolic elements, beliefs, and institutions of the community and nation-state. While schemas tend to remain stable over time, they can change in the course of social interaction (Hendi 20I7). Nation-states (communities) interact on the global (local) stage through exposure to material elements like consumer goods, media, technology, and national (local) institutional arrangements. All of these are material elements that may directly affect gender dynamics. But a material exchange can also affect gender dynamics through its impact on macro-structures that affect schemas. One example is advertisements that depict women as independent earners or breadwinners, or movies about women holding political roles. Other examples could be the use of mobile phones to track agendas promoted by female politicians, for instance, through SMS or the use of WhatsApp to join online forums to track the political engagement of female leaders within a village (Abubakar and Dasuki 20I8). Mobile phones may also enable greater communication and connectivity within communities and thus greater civic participation around specific issues, as well as swifter information flows within networks, with the potential to shift how women's roles are perceived. While these media may not directly cause people to change their attitudes toward the role of women, they can act through normative change to affect how people perceive female roles within society. In this sense, mobile phones can be crucial material elements acting through normative change to affect the macro-structural cultural scripts that communities or groups are exposed to, which in turn shape gender-related schemas at the individual level. 


\section{DATA AND METHODS}

In this study, we use data from the AfroBarometer's 2015 survey wave, which covers 36 African countries (Table I). The AfroBarometer is a pan-African research network that regularly conducts public-attitude surveys on democracy, governance, economic conditions, and related issues across African countries. Samples, usually of $\mathrm{I}, 200$ to 2,400 respondents, are designed to give every adult citizen an equal chance of being selected for an interview, making them representative cross-sections of all citizens of voting age in a given country. Table I reports the sample of AfroBarometer respondents for each country, alongside its Human Development Index (HDI) and the World Bank's "Global gender gap political empowerment" sub-index. In our sample of countries, Mauritius and Algeria have the highest HDI, at $0.78 \mathrm{I}$ and 0.745 , respectively, while Niger reports the lowest (0.353). The political empowerment sub-index measures gender gaps for the highest political decision-making roles, such as the ratio of women to men in minister-level and parliamentary positions, ${ }^{6}$ and is also on a o-to-I scale. South Africa reports the highest value (0.404), while Benin reports the lowest (0.067).

Figure I shows mobile-phone ownership rates for the subset of countries for which we have data, providing an overview of mobile penetration across the African continent. This indicator varies considerably across countries, from 33 percent in Burundi to 95 percent in Morocco.

Table 2 reports summary statistics for the main variables used in the estimation models by sex of the respondent. Our dependent variable across all model specifications is "Women same chance," which equals I for respondents agreeing with the statement that women should have equal access to political roles as men, and o otherwise. The main explanatory variable is a dummy for using mobile phones daily $(=\mathrm{I})$. We also construct a dummy variable for owning a mobile phone, and in the appendix we report parallel analyses using mobile-phone ownership as the main predictor. The dummy variable "Discuss politics" equals I for respondents who report discussing political matters when they get together with friends or family. Knowledge of English, French, or Arabic is also accounted for as a potential channel in the relationship of interest. ${ }^{8}$ The socioeconomic controls reported in the following rows are either binary or dichotomized categorical variables that equal I if the respondent is employed; male; has no, primary, secondary, or tertiary education; or lives in a rural area. Radio and TV ownership are also coded as dummies, while age and the number of adults living in the same household are continuous variables. The models also include respondents' economic conditions, on a scale from I (very bad) to 5 (very good). We further include in our analyses two macrolevel development and contextual indicators drawing on different data sources for the same year (2015): the $\mathrm{HDI}^{9}$ and the political empowerment sub-index. ${ }^{10}$

Given the nested nature of our data, with individuals nested within countries and subregions, and the binary nature of our dependent variable, the main statistical model we adopt is a multilevel mixed-effect probit regression, with the general form

$$
\text { Probit }\left(\text { same chance }_{i, j}\right)=\beta_{0}+\beta_{1} \text { OwnMobilePhone }_{1, i, j}+\beta_{n} X_{1, i, j}+\beta_{k} T_{2, j}+u_{j}
$$


TABLE 1. Human Development Index (HDI), Political Empowerment (Gender Gap) Sub-Index, and Sample Size, per Country

\begin{tabular}{|c|c|c|c|}
\hline Country & HDI & Political empowerment & Sample size \\
\hline Algeria & 0.745 & 0.205 & 1,200 \\
\hline Benin & 0.485 & 0.067 & 1,200 \\
\hline Botswana & 0.698 & 0.068 & 1,200 \\
\hline Burkina Faso & 0.402 & 0.068 & 1,200 \\
\hline Burundi & 0.404 & 0.314 & 1,200 \\
\hline Côte d'Ivoire & 0.474 & 0.081 & 1,199 \\
\hline Cape Verde & 0.648 & 0.343 & 1,200 \\
\hline Cameroon & 0.518 & 0.18 & 1,182 \\
\hline Gabon & 0.697 & & 1,198 \\
\hline Ghana & 0.579 & 0.112 & 2,400 \\
\hline Guinea & 0.414 & 0.13 & 1,200 \\
\hline Kenya & 0.555 & 0.182 & 2,397 \\
\hline Lesotho & 0.497 & 0.172 & 1,200 \\
\hline Liberia & 0.427 & 0.23 & 1,199 \\
\hline Madagascar & 0.512 & 0.142 & 1,200 \\
\hline Malawi & 0.476 & 0.113 & 2,400 \\
\hline Mali & 0.442 & 0.086 & 1,200 \\
\hline Mauritius & 0.781 & 0.087 & 1,200 \\
\hline Morocco & 0.647 & 0.11 & 1,200 \\
\hline Mozambique & 0.418 & 0.361 & 2,400 \\
\hline Niger & 0.353 & & 1,200 \\
\hline Nigeria & 0.527 & 0.097 & 2,400 \\
\hline Sao Tome and Principe & 0.574 & & 1,196 \\
\hline Senegal & 0.494 & 0.316 & 1,200 \\
\hline Sierra Leone & 0.42 & & 1,191 \\
\hline South Africa & 0.666 & 0.404 & 2,390 \\
\hline Swaziland & 0.541 & 0.109 & 1,200 \\
\hline Tanzania & 0.531 & 0.296 & 2,386 \\
\hline Togo & 0.487 & & 1,200 \\
\hline Tunisia & 0.725 & & 1,200 \\
\hline Uganda & 0.493 & 0.26 & 2,400 \\
\hline Zambia & 0.579 & & 1,199 \\
\hline Zimbabwe & 0.516 & 0.175 & 2,400 \\
\hline
\end{tabular}




\section{Mobile phone ownership}
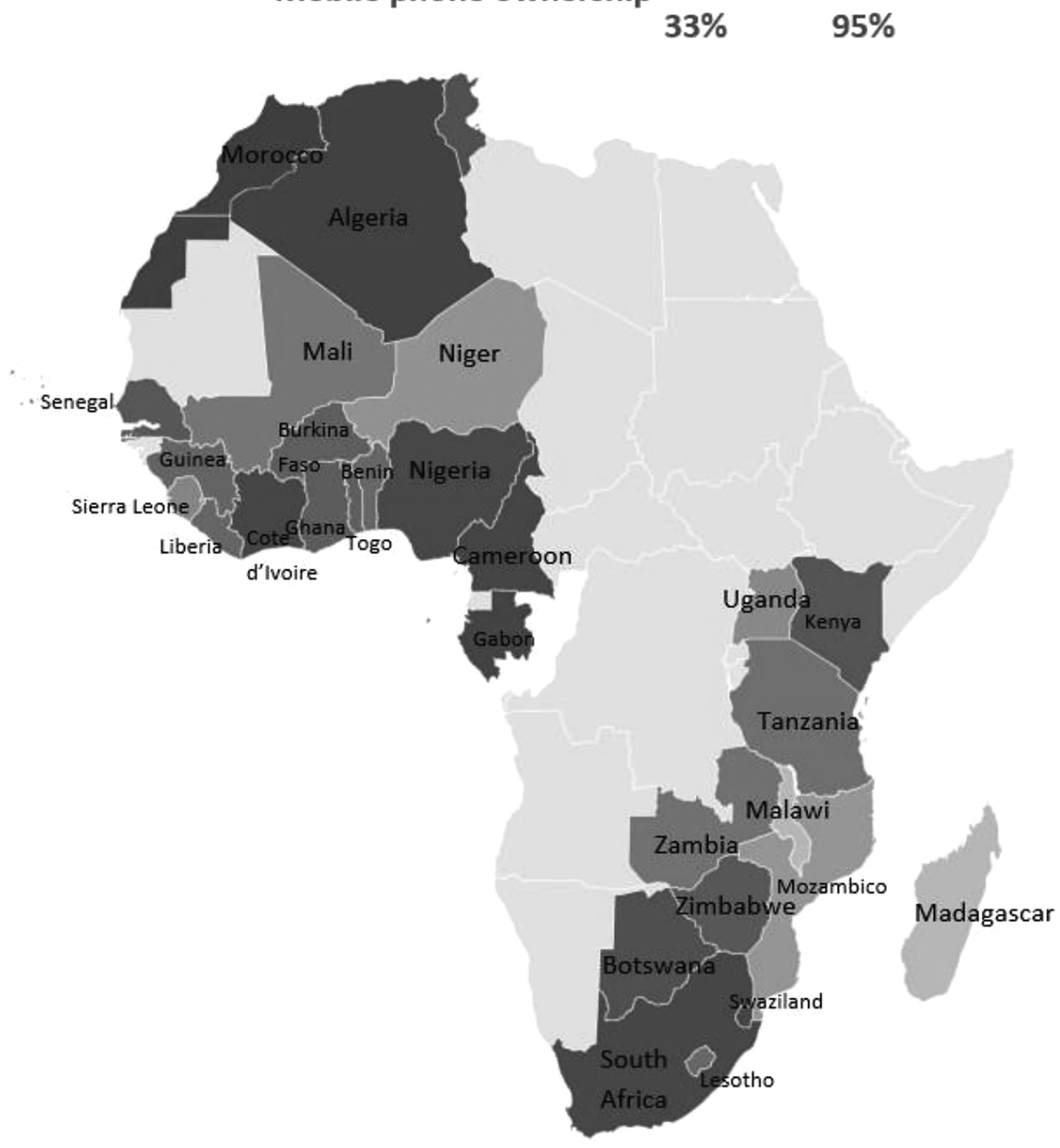

FIGURE 1. Mobile-phone ownership by country.

The probability that respondent $i$ from country $j$ believes that women should have the same chance of being elected to political office is thus allowed to depend on both level I and level 2 covariates. The subscript $\mathrm{I}, i, j$ identifies variables that change at the individual level $i$ and the country level $j$, whereas the subscript $2, j$ captures those that vary only at the country level $j$. The former includes the main predictor of interest, mobile-phone use, and the sociodemographic and economic characteristics of respondents and households. Alongside age, personal economic conditions, employment status, education, living in rural areas, the number of adults in the household, and TV and radio ownership, the models include a squared term for age to test for curvilinear trends, and two interaction terms: between mobile-phone use and age, and between mobile-phone use and employment status. We include the latter interaction in light of the literature from Japan mentioned above, suggesting that mobile phones may reinforce and reproduce the existing social role of Japanese housewives vis-à-vis working women (Dobashi 2005). $X_{\mathrm{I}, i, j}$ also includes knowledge of English, French, or Arabic and whether respondents discuss 
TABLE 2. Summary Statistics, by Sex of Respondent

\begin{tabular}{|c|c|c|c|c|}
\hline \multirow[b]{2}{*}{ Variable } & \multicolumn{2}{|c|}{ Male } & \multicolumn{2}{|c|}{ Female } \\
\hline & Mean & $\begin{array}{l}\text { (Std. } \\
\text { Dev.) }\end{array}$ & Mean & $\begin{array}{l}\text { (Std. } \\
\text { Dev.) }\end{array}$ \\
\hline \multicolumn{5}{|l|}{ Dependent variable } \\
\hline Women same chance of being elected as men & 0.612 & & 0.744 & \\
\hline \multicolumn{5}{|l|}{ Independent variables } \\
\hline Use mobile phone daily & 0.75 & & 0.657 & \\
\hline Own mobile phone & 0.82 & & 0.731 & \\
\hline \multicolumn{5}{|l|}{ Instrumental variable } \\
\hline $\begin{array}{l}\text { Cell phone service in the primary sampling unit / census } \\
\text { enumeration area }\end{array}$ & 0.935 & & 0.932 & \\
\hline \multicolumn{5}{|l|}{ Possible mechanisms and control variables } \\
\hline Discuss politics & 0.748 & & 0.613 & \\
\hline English/French/Arabic & 0.313 & & 0.264 & \\
\hline Employed (waged job) & 0.438 & & 0.328 & \\
\hline No education & 0.160 & & 0.222 & \\
\hline Primary education & 0.281 & & 0.313 & \\
\hline Secondary education & 0.388 & & 0.34 & \\
\hline Tertiary education & 0.171 & & 0.125 & \\
\hline Rural & 0.587 & & 0.586 & \\
\hline Own radio & 0.764 & & 0.643 & \\
\hline Own TV & 0.504 & & 0.466 & \\
\hline Age & 38.57 & $(15.214)$ & 36.15 & (13.82) \\
\hline Adults in household & 4.07 & $(2.76)$ & 3.876 & $(2.604)$ \\
\hline \multicolumn{5}{|l|}{ Personal economic conditions } \\
\hline Very bad & 0.019 & & 0.197 & \\
\hline Bad & 0.278 & & 0.273 & \\
\hline Neither good nor bad & 0.205 & & 0.206 & \\
\hline Good & 0.276 & & 0.279 & \\
\hline Very good & 0.04 & & 0.04 & \\
\hline
\end{tabular}

politics with family and friends, a set of variables which we leverage to test for potential mechanisms in a subsequent stage. Conversely, the latter vector includes the HDI and the political empowerment index. Multilevel models are particularly suited for this type of 
analysis since individuals are nested within countries and sub-regions and since the empirical models include two variables at the country level. Yet, the results are robust to the alternative adoption of a simple probit model, a linear probability model with standard errors clustered at the country level, and a probit model with country fixed effects (hence, no level-2 covariates) to test for additional country-level factors that could influence the relationship between mobile-phone use and attitudes (Tables A2, A3, and $\mathrm{A}_{4}$ in the appendix).

Although multilevel models account for the nested structure of the data, they do not by themselves permit us to address the issue of endogeneity of the main explanatory variables, those related to mobile-phone use, thus limiting the causal interpretation of the estimates. Endogeneity may arise from unobserved heterogeneity at the individual level in mobile-phone use and/or reverse causality. To address endogeneity concerns as best as possible given our cross-sectional setup, we make use of instrumental variable estimation techniques. The geo-localized version of the AfroBarometer data reports whether the local geographical unit where the respondent lives is under mobile-phone-network coverage. As in Rotondi et al. (2020) and Pesando (forthcoming), we use this indicator as an exogenous instrument for mobile-phone use (parallel analyses of mobile-phone ownership are reported in the appendix). Our estimation thus indicates on a O-to-I scale how good mobile-phone coverage is in the primary sampling unit, which is the smallest geographic unit for which reliable population data are available, and almost always coincides with census enumeration areas. Mobile-phone-network coverage is expected to increase the probability of owning and using a mobile device (instrument relevance). At the same time, it is outside of individual control and highly dependent on geographical factors (hills, mountains, valleys, and so on), hence arguably unrelated to individual-level attitudes (instrument exogeneity). ${ }^{11}$ Since our dependent variable and our endogenous regressor are both binary, we face a so-called forbidden regression scenario, and we implement an estimation procedure including two-stage least squares, with a linear first stage and a probit second-stage regression (Angrist and Pischke 2008).

\section{RESULTS}

\section{Association between Mobile-Phone Use and Attitudes toward Women in Politics}

Table 3 reports results from multilevel probit regressions predicting the probability that the respondent agrees with the statement that women should have the same chance of being elected to political office as men.

We start by considering coefficients on control variables to provide a preliminary assessment of the empirical specification. Men's likelihood of agreeing with the statement that women should have the same chance of being elected to political office as men is approximately $\mathrm{I} 3$ percentage points lower than women's (column I). Support for women's participation in politics increases steeply with education. More specifically, respondents holding tertiary education degrees are, on average, II percentage points more likely than respondents with no education to support women's participation in political roles (column I). Owning a radio is also positively and significantly related to attitudes toward 
TABLE 3. Associations between Daily Mobile-Phone Use and Attitudes toward Women in Politics

\begin{tabular}{|c|c|c|c|}
\hline & $\begin{array}{c}(1) \\
\text { Overall } \\
b / S E\end{array}$ & $\begin{array}{c}\text { (2) } \\
\text { Women } \\
\text { b/SE }\end{array}$ & $\begin{array}{l}\text { (3) } \\
\text { Men } \\
b / S E\end{array}$ \\
\hline \multirow[t]{2}{*}{ Use mobile phone daily } & $0.053^{\star \star \star}$ & $0.042^{\star \star \star}$ & $0.020^{\star}$ \\
\hline & $(0.008)$ & $(0.008)$ & $(0.011)$ \\
\hline \multirow[t]{2}{*}{ Age } & $0.001^{\star}$ & 0.002 & 0.001 \\
\hline & $(0.001)$ & $(0.001)$ & $(0.001)$ \\
\hline \multirow[t]{2}{*}{ Age squared } & -0.000 & -0.000 & 0.000 \\
\hline & $(0.000)$ & $(0.000)$ & $(0.000)$ \\
\hline \multirow[t]{2}{*}{ Personal econ . conditions = fairly bad } & $-0.016^{\star \star}$ & -0.010 & $-0.022^{\star \star}$ \\
\hline & $(0.007)$ & $(0.009)$ & $(0.010)$ \\
\hline \multirow{2}{*}{ Personal econ. conditions $=$ neither good nor bad } & $-0.015^{\star \star}$ & -0.007 & $-0.025^{\star \star}$ \\
\hline & $(0.007)$ & $(0.010)$ & $(0.011)$ \\
\hline \multirow[t]{2}{*}{ Personal econ. conditions $=$ good } & -0.002 & -0.007 & 0.003 \\
\hline & $(0.007)$ & $(0.009)$ & $(0.010)$ \\
\hline \multirow{2}{*}{ Personal econ. conditions $=$ very good } & $-0.022^{\star}$ & $-0.037^{\star \star}$ & -0.007 \\
\hline & $(0.012)$ & $(0.015)$ & $(0.018)$ \\
\hline \multirow[t]{2}{*}{ Own radio } & $0.017^{\star \star \star}$ & $0.012^{\star}$ & $0.017^{\star \star}$ \\
\hline & $(0.005)$ & $(0.007)$ & $(0.008)$ \\
\hline \multirow[t]{2}{*}{ Own TV } & -0.003 & -0.004 & -0.003 \\
\hline & $(0.006)$ & $(0.008)$ & $(0.009)$ \\
\hline \multirow[t]{2}{*}{ Employed (waged job) } & 0.015 & $0.030^{\star \star}$ & -0.000 \\
\hline & $(0.009)$ & $(0.012)$ & $(0.014)$ \\
\hline \multirow[t]{2}{*}{ Male } & $-0.129^{\star \star \star}$ & & \\
\hline & $(0.009)$ & & \\
\hline \multirow[t]{2}{*}{ Primary education } & $0.020^{\star \star \star}$ & $0.015^{\star}$ & $0.024^{\star \star}$ \\
\hline & $(0.007)$ & $(0.009)$ & $(0.011)$ \\
\hline \multirow[t]{2}{*}{ Secondary education } & $0.067^{\star \star \star}$ & $0.050^{\star \star \star}$ & $0.084^{\star \star \star}$ \\
\hline & $(0.008)$ & $(0.010)$ & $(0.012)$ \\
\hline \multirow[t]{2}{*}{ Tertiary education } & $0.112^{\star \star \star}$ & $0.084^{\star \star \star}$ & $0.136^{\star \star \star}$ \\
\hline & $(0.010)$ & $(0.013)$ & $(0.014)$ \\
\hline
\end{tabular}


TABLE 3. Associations between Daily Mobile-Phone Use and Attitudes toward Women in Politics (continued)

\begin{tabular}{|c|c|c|c|}
\hline & $\begin{array}{c}(1) \\
\text { Overall } \\
b / \mathrm{SE}\end{array}$ & $\begin{array}{c}(2) \\
\text { Women } \\
b / S E\end{array}$ & $\begin{array}{l}\text { (3) } \\
\text { Men } \\
b / S E\end{array}$ \\
\hline \multirow[t]{2}{*}{ Rural } & $-0.017^{\star \star \star}$ & $-0.018^{\star \star \star}$ & $-0.014^{\star}$ \\
\hline & $(0.005)$ & $(0.007)$ & $(0.008)$ \\
\hline \multirow[t]{2}{*}{ Adults in household } & $-0.003^{\star \star \star}$ & $-0.002^{*}$ & $-0.004^{\star \star \star}$ \\
\hline & $(0.001)$ & $(0.001)$ & $(0.001)$ \\
\hline \multirow[t]{2}{*}{ Mobile phone $\times$ male } & $-0.040^{\star \star \star}$ & & \\
\hline & $(0.010)$ & & \\
\hline \multirow[t]{2}{*}{ Mobile phone $\times$ employed } & $-0.027^{\star \star}$ & $-0.030^{\star \star}$ & -0.015 \\
\hline & $(0.011)$ & $(0.014)$ & $(0.016)$ \\
\hline \multirow[t]{2}{*}{ Human Development Index } & -0.008 & 0.172 & -0.202 \\
\hline & $(0.213)$ & $(0.198)$ & $(0.240)$ \\
\hline \multirow[t]{2}{*}{ Political empowerment (gender gap) subindex } & 0.231 & 0.181 & 0.277 \\
\hline & $(0.221)$ & $(0.206)$ & $(0.249)$ \\
\hline N & 40,266 & 18,722 & 16,798 \\
\hline
\end{tabular}

women in politics, whereas living in rural areas and larger households are negatively related. Support for women in politics is also higher among older individuals. This result, which might sound somewhat counter-intuitive, is in line with Pierotti's (2013) study on global diffusion mechanisms in rejection of IPV and, partially, with Charles (2020). The latter found that older men support gender equality (measured as support for equal gender rights) more than younger ones, whereas this does not hold for older women. Level-2 regression coefficients show that both HDI and women's political empowerment are not statistically significantly associated with attitudes toward women in politics. The direction of the coefficient for HDI interestingly differs between men and women, with a small (near-zero) coefficient in the pooled model. While higher HDI is associated with more support among women, the coefficient's negative sign suggests less support among men in higher-HDI countries. We note that the size of the coefficient for women's political empowerment is sizeable and positive across all three columns, and hence in the expected direction, yet it is not statistically significant. This may also be due to sample size issues, because this variable is not available for all countries (Table I).

Moving on to our key explanatory variable, column I suggests that owning a mobile phone increases the likelihood of a respondent's agreeing with women's participation in 
politics by about 5.3 percentage points. Columns 2 and 3 are restricted to female and male respondents, respectively, and column 2 shows that the association of mobile-phone ownership with attitudes is stronger (about double) for the sub-sample of female respondents. In line with the above hypotheses, in column I the interaction term between being male and using a mobile phone is negative and statistically significant. The same holds for the interaction between mobile-phone use and employment status, yet columns 2 and 3 suggest that this negative interaction is fully driven by the subsample of women. By suggesting that the positive association between mobile-phone use and attitudes toward female representation in politics is smaller (close to null) for employed women, our findings point to a key role of technology for more vulnerable women, such as housewives or women in non-wage occupations. This is in line with Suri and Jack (2016), who found mobile money to be more effective among unemployed women, yet it differs from Dobashi's (2005) findings, which suggest that mobile phones in Japan reinforce and reproduce the existing social role of Japanese housewives vis-à-vis working women.

Table AI in the appendix reports results on the extensive margin of mobile-phone ownership (i.e., using a dummy variable for owning a mobile phone as the main predictor) and shows even stronger gender differences on the mobile-phone variable, with a coefficient that is close to null for men. ${ }^{12}$ Thus, Tables 3 and AI combined suggest that what positively influences respondents' views on female political roles is rather the intensive margin of mobile-phone use, that is, the act of using it daily. Although this finding does not itself provide enough evidence about how individuals use their phones, as the AfroBarometer does not contain explicit information on the types of use of mobile devices, it more solidly hints at the possibility of more active and possibly varied use of mobile phones, with greater opportunities for information exchange and social learning. The results shown so far are robust to the use of different empirical models, as shown in Tables $\mathrm{A}_{2}, \mathrm{~A}_{3}$, and $\mathrm{A}_{4}$ in the appendix (using a simple probit, a linear probability model with standard errors clustered at the country level, and a probit accounting for country dummies, respectively).

Channels possibly underlying some of these results are explored in Table 4. Knowledge of either English, French, or Arabic is statistically significant. However, it is non-significant when interacted with daily mobile-phone use, suggesting that the mobile phone association is not amplified among those who self-report speaking any one of these languages, which could be an indication of foreign-media exposure. The results for the other mechanism, discussing political matters when respondents get together with friends or family, is insignificant as well, although the coefficient's sign is positive. Neither variable, therefore, allows us to precisely estimate some of the mechanisms theorized above, such as exposure to foreign media or engagement with political discussion. This aspect needs to be explored in greater depth in future research as more waves of data become available, but we believe it might partly reflect measurement issues in these moderators.

\section{Instrumental Variable Estimates}

While positive, sizeable, and statistically significant, the relationships uncovered in the previous section suffer from the potential endogeneity of the mobile-phone variables. In 
TABLE 4. Associations between Mobile-Phone Daily Use and Attitudes toward Women in Politics: Potential Channels

(1)

Women same chance of being elected as men $(b / S E)$

$\begin{array}{lc}\text { Use mobile phone daily } & 0.053^{\star \star \star} \\ \text { English/French/Arabic } & (0.008) \\ & 0.094^{\star \star \star} \\ \text { Use mobile phone daily } \times \text { English/French/Arabic } & (0.031) \\ & -0.009 \\ & (0.030)\end{array}$

Discuss politics

$-0.003$

(0.025)

Use mobile phone daily $\times$ Discuss politics

0.025

$(0.031)$

Use mobile phone daily $\times$ Male

$-0.037^{\star \star \star}$

$-0.123^{\star \star \star}$

(0.010)

(0.030)

Use mobile phone daily $\times$ Employed

$-0.030^{* \star \star}$

$-0.090^{\star \star \star}$

(0.011)

(0.032)

Human Development Index

$-0.026$

$-0.022$

(0.215)

$(0.644)$

Political empowerment (gender gap) subindex

0.241

0.698

$(0.224)$

$(0.673)$

Age

$0.002^{* *}$

$0.004^{\star}$

(0.001)

(0.002)

Age squared

0.000

0.000

Personal econ. conditions $=$ fairly bad

0.000

0.000

$-0.015^{\star \star}$

$-0.053^{\star \star \star}$

(0.007)

(0.020)

Personal econ. conditions $=$ neither good nor bad

$-0.013^{\star}$

$-0.049^{\star \star}$

(0.007)

(0.022)

Personal econ. conditions $=$ good

$-0.001$

$-0.005$

(0.007)

(0.021)

Personal econ. conditions $=$ very good

$-0.024^{\star \star}$

$-0.066^{\star}$

(continued) 
TABLE 4. Associations between Mobile-Phone Daily Use and Attitudes toward Women in Politics: Potential Channels (continued)

(1)

Women same chance of being elected as men $(b / S E)$

\begin{tabular}{|c|c|c|}
\hline & $(0.012)$ & $(0.036)$ \\
\hline \multirow[t]{2}{*}{ Own radio } & $0.018^{\star \star \star}$ & $0.049^{* \star *}$ \\
\hline & $(0.005)$ & $(0.016)$ \\
\hline \multirow[t]{2}{*}{ Own TV } & -0.003 & -0.011 \\
\hline & $(0.006)$ & $(0.018)$ \\
\hline \multirow[t]{2}{*}{ Employed (waged job) } & 0.013 & $0.051^{\star}$ \\
\hline & $(0.009)$ & $(0.028)$ \\
\hline \multirow[t]{2}{*}{ Male } & $-0.130^{\star \star \star}$ & $-0.393^{\star \star \star}$ \\
\hline & $(0.009)$ & $(0.025)$ \\
\hline \multirow[t]{2}{*}{ Primary education } & $0.018^{\star \star}$ & $0.064^{\star \star \star}$ \\
\hline & $(0.007)$ & $(0.021)$ \\
\hline \multirow[t]{2}{*}{ Secondary education } & $0.066^{\star \star \star}$ & $0.207^{\star \star \star}$ \\
\hline & $(0.008)$ & $(0.023)$ \\
\hline \multirow[t]{2}{*}{ Tertiary education } & $0.110^{\star \star \star}$ & $0.339^{\star \star \star}$ \\
\hline & $(0.010)$ & $(0.028)$ \\
\hline \multirow[t]{2}{*}{ Rural } & $-0.013^{\star \star}$ & $-0.051^{\star \star \star}$ \\
\hline & $(0.005)$ & $(0.016)$ \\
\hline \multirow[t]{2}{*}{ Adults in household } & $-0.003^{\star \star \star}$ & $-0.009^{\star \star \star}$ \\
\hline & $(0.001)$ & $(0.003)$ \\
\hline$N$ & 40,070 & 40,742 \\
\hline
\end{tabular}

${ }^{\star} p<0.10,{ }^{\star \star} p<0.05,{ }^{\star \star \star} p<0.01$.

Note: Multilevel probit model marginal coefficient tables. Reference category for education: no education; reference category for personal economic conditions: very bad.

the above specifications, we attempted to control for a rich set of observed factors both at the individual level, with variables for socioeconomic status, age, household structure, and so on, and at the macro level, with development indicators such as the HDI and the gender gap in political empowerment. However, the risk of omitted-variable bias remains. For example, we may not have adequately captured unobserved underlying cultural norms or societal-development dynamics that could affect both women's use of mobile phones and their attitudes toward gender roles. Likewise, we cannot exclude a priori the possibility of reverse causality, which would occur if women with more gender-egalitarian attitudes toward politics were more likely to use mobile phones. 
For this reason, we identified a variable that is positively related to the probability of using a mobile phone but (arguably) not with other factors affecting the outcome. We use mobile-service coverage in the primary sampling unit as an instrumental variable for our predictor of interest, namely daily use. Table 5 shows the coefficients (marginal effects) of two-stage least-squares probit regressions with mobile-service coverage used as an instrument for the probability of using a mobile phone daily. The results confirm that the relationship between daily mobile-phone use and beliefs toward women's role in politics is robust to the use of the instrumental variable at the 5 percent significance level. Importantly, across both outcomes the instrumental variable estimates confirm the positive and significant coefficients only for the sub-sample of women, with negative and non-significant coefficients for men. The magnitude of the coefficients suggests that daily mobile-phone use leads to an increase in women's positive attitudes toward female participation in politics by about II percentage points. Note that the size of the coefficient is 2 to 3 times greater than in both multilevel and probit models, suggesting a downward bias driven by either measurement error in the mobile-phone predictor, or validity concerns related to the instrument. For reference, Table As in the appendix reports results from the first-stage regressions, which are strongly significant in both models, suggesting that service coverage can be deemed a relevant predictor of daily use of mobile phones. Lastly, Table A6 provides instrumental variable estimates using mobile-phone ownership as the main predictor. As before, the coefficient of interest is greater in magnitude than the mobile-phone use one and remains strongly statistically significant for the female sample only. This coefficient suggests that mobile-phone ownership leads to an increase in women's positive attitudes toward female participation in politics by about I 4.8 percentage points, while the coefficient is null for men.

TABLE 5. Daily Mobile-Phone Use and Attitudes toward Women in Politics: Instrumental Variable Two-Stage Least-Squares Probit

\begin{tabular}{lccc}
\hline & $\begin{array}{c}(1) \\
\text { Overall } \\
b / \mathrm{SE}\end{array}$ & $\begin{array}{c}(2) \\
\text { Women } \\
b / \mathrm{SE}\end{array}$ & $\begin{array}{c}(3) \\
\text { Men } \\
b / \mathrm{SE}\end{array}$ \\
\hline Use mobile phone daily (fitted values) & 0.038 & $0.114^{\star}$ & -0.050 \\
& $(0.069)$ & $(0.066)$ & $(0.092)$ \\
Age & 0.001 & 0.000 & 0.001 \\
Age squared & $(0.001)$ & $(0.001)$ & $(0.001)$ \\
& 0.000 & -0.000 & 0.000 \\
Personal econ. conditions $=$ fairly bad & $(0.000)$ & $(0.000)$ & $(0.000)$ \\
& -0.008 & -0.007 & -0.008 \\
& $(0.012)$ & $(0.012)$ & $(0.016)$ \\
\hline
\end{tabular}


TABLE 5. Daily Mobile-Phone Use and Attitudes toward Women in Politics: Instrumental Variable Two-Stage Least-Squares Probit (continued)

\begin{tabular}{|c|c|c|c|}
\hline & $\begin{array}{c}(1) \\
\text { Overall } \\
b / S E\end{array}$ & $\begin{array}{c}\text { (2) } \\
\text { Women } \\
\text { b/SE }\end{array}$ & $\begin{array}{l}(3) \\
\text { Men } \\
b / S E\end{array}$ \\
\hline \multirow[t]{2}{*}{ Personal econ. conditions $=$ neither good nor bad } & -0.011 & -0.014 & -0.008 \\
\hline & $(0.018)$ & $(0.019)$ & $(0.021)$ \\
\hline \multirow[t]{2}{*}{ Personal econ. conditions = good } & -0.012 & -0.018 & -0.005 \\
\hline & $(0.019)$ & $(0.018)$ & $(0.022)$ \\
\hline \multirow[t]{2}{*}{ Personal econ. conditions $=$ very good } & $-0.053^{\star \star}$ & $-0.077^{\star \star}$ & -0.027 \\
\hline & $(0.027)$ & $(0.031)$ & $(0.027)$ \\
\hline \multirow[t]{2}{*}{ Own radio } & 0.017 & 0.008 & 0.025 \\
\hline & $(0.013)$ & $(0.013)$ & $(0.016)$ \\
\hline \multirow[t]{2}{*}{ Own TV } & -0.021 & -0.016 & -0.022 \\
\hline & $(0.023)$ & $(0.023)$ & $(0.025)$ \\
\hline \multirow[t]{2}{*}{ Employed (waged job) } & -0.012 & 0.017 & $-0.046^{\star \star}$ \\
\hline & $(0.014)$ & $(0.017)$ & $(0.022)$ \\
\hline \multirow[t]{2}{*}{ Male } & $-0.147^{\star \star \star}$ & & \\
\hline & $(0.014)$ & & \\
\hline \multirow[t]{2}{*}{ Primary education } & $0.055^{\star \star \star}$ & $0.044^{\star \star}$ & $0.066^{\star \star \star}$ \\
\hline & $(0.020)$ & $(0.022)$ & $(0.021)$ \\
\hline \multirow[t]{2}{*}{ Secondary education } & $0.112^{\star \star \star}$ & $0.091^{\star \star \star}$ & $0.132^{\star \star \star}$ \\
\hline & $(0.025)$ & $(0.028)$ & $(0.026)$ \\
\hline \multirow[t]{2}{*}{ Tertiary education } & $0.134^{\star \star \star}$ & $0.110^{\star \star \star}$ & $0.156^{\star \star \star}$ \\
\hline & $(0.027)$ & $(0.031)$ & $(0.027)$ \\
\hline \multirow[t]{2}{*}{ Rural } & $-0.023^{\star \star}$ & $-0.026^{\star \star}$ & -0.019 \\
\hline & $(0.011)$ & $(0.012)$ & $(0.013)$ \\
\hline N & 49,183 & 24,638 & 24,545 \\
\hline
\end{tabular}

${ }^{\star} p<0.10,{ }^{\star \star} p<0.05,{ }^{\star \star \star} p<0.01$.

Note: Marginal coefficient tables. Reference category for education: no education; reference category for personal economic conditions: very bad.

\section{CONCLUSIONS}

This study has contributed knowledge to the literature on the relationship between technology adoption and gender equality, focusing on a domain of gender equality that has been neglected in the literature, namely political representation. Specifically, we 
examined whether use of mobile phones shapes gender attitudes toward women's participation in politics by making it more widely acceptable that women hold institutional roles. We analyze this relationship across 36 countries in Africa, a geographical context where women's participation in politics and policymaking remains highly restricted, even when it comes to agendas that impact women's own lives (Nyemba-Mudenda and Chigona 20I8). Existing theoretical and empirical evidence points to the importance of ideological factors, such as attitudes about women's participation in politics, for explaining women's political representation (Paxton and Kunovich 2003); yet research also points to how across the world attitudes toward women in politics are more conservative than those toward gender inequality in other domains, such as women in education (Price 2014). Building on theoretical and empirical work that has highlighted a salient role for mass media and ICTs in spreading new ideas by enabling new paths for mutual information exchange and social learning, we explore the effects of the key ICT of the new millennium, mobile phones. Mobile phones are especially relevant in the African context as they represent the first widespread telecommunication infrastructure in a continent where landline penetration has remained low and even declined (Aker and Mbiti 20I0).

We hypothesize that greater mobile-phone use-irrespective of whether it provides online connectivity-may increase the subjective legitimacy of female representation in the public sphere by expanding individual (but especially women's) networks, improving communication and connectivity, and expanding access to information and media, including more global and liberalized cultural scripts. Women's networks are expanded in such a way that access to information that was previously restricted to either inperson social networks or unidirectional mass media such as radio or TV becomes widely, quickly, and cheaply available, kickstarting a shift in women's attitudes toward their own roles within society. Our results are as we expected, with a strong positive association between mobile technology and gender-egalitarian attitudes toward women's participation in politics. The significant relationship is robust to the use of instrumental variable techniques and is observed only among female respondents. It is also robust to the use of an alternative predictor, measuring mobile-phone ownership rather than mobile-phone use. These results provide large-scale quantitative evidence in line with qualitative work from Africa and other contexts (e.g., Abubakar and Dasuki 20I8; GSMA 20IO) highlighting the role of mobile phones in enabling women to participate more actively in their communities and engage with each other on political issues.

The positive association between mobile-phone use and changing attitudes toward women's participation in politics aligns with the idea that mobile phones can serve as crucial material elements acting through normative change to affect gender-related schemas. Through enhanced social interaction triggered by the use of mobile phones, changing gender schemas reflect a gradual process of transforming symbolic elements, beliefs, and institutions of communities and nation-states toward more openness and acceptance of notions of equality. Thus, our results for women suggest that mobile technology can be a lever through which attitudes to women's status in the political arena are reshaped. Indeed, we also acknowledge that the full potential of mobile technologies is contingent 
on the closing of digital divides, both access-related and skill-related, by gender-still a pressing issue across many LMICs.

The null finding for men is interesting and novel, yet puzzling. We advance two possible explanations. On the one hand, it may be that men are exposed to the same type of information that women are exposed to, yet, living in societies where social norms strongly favor men, the transformative beliefs and ideals that "mobile" information conveys are not strong enough to shift their preconceptions. Further, men may already have well-established networks outside of co-resident kin ties, such as through market work, and mobile phones may not enable a widening of networks for new forms of social learning and exchange as they do for women.

On the other hand, it is possible that the content men are exposed to-or the type of information they seek and access through mobile phones-is of a different nature. For instance, they might be more exposed to traditional notions of women's roles in society, gender stereotypes, or even sexist and discriminatory information that is propagated through mainstream films, often with few female characters and strong and violent masculine ones. Evidence from Malawi suggests that men are particularly prone to consuming this type of (foreign) entertainment media (Gray 2OII, 20I4). Research in the United States provides further evidence of negative gender attitudes resulting from entertainment media displaying such gender stereotypes (Ward 20I6). Men and women may also use technology for different purposes-for example, men may use it more for leisure, such as watching videos or films, whereas women, whose time may be more circumscribed due to family-care responsibilities, may use phones in more practical ways to meet specific needs linked to communication, finance, or learning. The limited range of mobile-use measures in the data limits our ability to test this, but further research is needed to unpack these differences. Interestingly, while previous research examining the effects of TV (not radio, see Forsyth and Ward 202I) on domestic violence have found gender differences in effects (Banerjee, La Ferrara, and Orozco 2019; Okenwa-Emegwa, Lawoko, and Jansson 2016), it has tended to find positive effects for men but none for women, the opposite of the pattern we find. These differences likely reflect the nature of the outcome under consideration. While reducing domestic violence requires men to reconsider themselves, attitudes to women's political participation require a reconsideration of women's status. Alternately, as research by Price (2014) suggests, attitudes to women in politics may be more resistant to change than those in other domains due to a more fundamental conflict with women's family-related roles.

The paper has some limitations that we hope will spur additional research on the topic. First and foremost, we have mentioned multiple times that our main predictor measures the use of mobile phones but not how they are used. We hypothesize different mechanisms linked to access to information as well as better connectivity, and access to wider networks beyond co-resident kin, but we cannot test these mechanisms with the data. We also cannot measure here how mobile phones generate changes in gender attitudes, such as the size and strength of women's mobilization locally, the availability of female role models already in positions of power, and, once again, the type of information women access through their phones. Our goal in this work was to test a general 
hypothesis drawing on existing theoretical frameworks to favor broad geographical coverage and identify a robust association, rather than testing the exact mechanism(s). Although large-scale social surveys such as the AfroBarometer and the Demographic and Health Surveys have recently begun to incorporate digital connectivity measures, recognizing the importance of these technologies in the global South, longitudinal data on technology diffusion and attitudes are still lacking, which ultimately limits our ability to analyze changes over time and make solid causal claims. By relying on an instrumental variable that has proved valid in other contexts (Pesando, forthcoming; Rotondi et al. 2020), we here provide a first attempt toward making the analysis more causally compelling, yet we acknowledge that mobile-phone coverage in the primary sampling unit may be correlated with other contextual factors (e.g., development processes, state infrastructure) that potentially weaken our instrument.

Relatedly, the AfroBarometer does not provide details on the type of phones individuals own (e.g., basic feature phones, hybrid smart feature phones, or smartphones) or whether the phones are Internet-enabled. However, for many of the mechanisms to be effective, even simple feature phones are sufficient, and studies from Africa indicate that these devices are powerful at closing information gaps, providing media access, and enabling better connectivity and access to services (Pesando and Rotondi 2020; Rotondi et al. 2020; Suri and Jack 2016). Second, although our data include whether mobile-phone users are male or female, shared device use is common in Africa, particularly for women (Blumenstock and Eagle 20IO). Thus, within households men may continue to have some control over the type of content that women access. Additional research on decision-making power within households vis-à-vis technology—alongside studies focused on differential digital skills between male and female partners within couples-might shed more light on this point. Lastly, our analyses only cover a selected sample of African countries. Therefore, we do not rule out the possibility that results might look different if all African countries were to be taken into account.

Despite these limitations, this study complements the growing literature on technology adoption and social development outcomes by suggesting that investing in cheaper, equitable access, enabling independent ownership, and focusing on ICT skill development, especially among women, is a promising pathway to leverage technology for sustainable development and, foremost, SDG 5. Yet this investment can only be fully effective-and mobile phones a universal tool for positive change-if it is inserted within a broader package of context-sensitive policies targeting poverty and rooted social norms in all their forms. Within this comprehensive policy package, our null result on the men's sample also suggests the need to devise strategies aimed at changing gender attitudes among men, which often prove far more resistant to change. Thus, changing gender attitudes among men might require policies structured around targeted educational, gender-sensitive, and awareness-raising interventions, starting from early ages, and accompanied by institutional reforms aimed at making women's economic contributions within and outside the household both more valuable and more visible. 
Carlotta Varriale is a PhD Candidate in Public Policy and Administration at the Department of Social and Political Sciences, Bocconi University. Her research interests are in the areas of governance and regulation of local government, reorganization of public-health agencies, and dynamics of gender inequality.

Luca Maria Pesando is an Assistant Professor of Sociology and Demography at the Department of Sociology and Centre on Population Dynamics, McGill University. His research interests are in the areas of social, economic, and digital demography, with a focus on the intergenerational implications of family change for educational and gender inequalities.

RIDHI KASHYAP is an Associate Professor of Social Demography at the Department of Sociology, Leverhulme Centre for Demographic Science, and Nuffield College, University of Oxford. Her research interests are in the areas of demographic change, health and mortality, gender inequality, digital technology, and computational social science.

Valentina Rotondi is a Researcher at the University of Applied Sciences and Arts of Southern Switzerland and Associate Researcher at the Leverhulme Centre for Demographic Science, University of Oxford. Her research interests are in the areas of applied social science, experimental economics, socioeconomic development, demographic change, and technological progress.

\section{FUNDING AND ACKNOWLEDGMENTS}

This project received funding from the European Research Council under the European Union Horizon 2020 research and innovation programme (Fund \#: 694262), project DisCont-Discontinuities in Household and Family Formation (PI: Billari). CV acknowledges support from Bocconi University. RK and VR acknowledge support from the Leverhulme Trust through the Leverhulme Centre for Demographic Science, University of Oxford. LMP acknowledges support from the School of Arts at McGill University, the Internal Social Science and Humanities Development Grant at McGill University (Fund \#: 253338), and the Insight Development Grant (Fund \#: 430-202I-00I47) awarded by the Social Sciences and Humanities Research Council of Canada (PI: Pesando). Preliminary analyses for this project were developed as a didactic exercise carried out during the first-year PhD course in Social Statistics held at Bocconi University within the $\mathrm{PhD}$ program in Social and Political Sciences and taught by VR. VR would like to thank all the students who took part in the course and who contributed to the preliminary idea: Carlotta Varriale, Rebecca Kirley, Colombe Ladreit, Chen Peng, Umberto Platini, and Juan Pablo Ripamonti.

\section{NOTES}

I. "Goal 5: Achieve gender equality and empower all women and girls" (https://www.un.org/ sustainabledevelopment/gender-equality/).

2. IPU Parline, "Monthly Ranking of Women in National Parliaments" (https://data.ipu.org/ women-ranking?month $=7$ \&year $=2019$ ).

3. Note, however, that results from Uganda and South Africa suggest that other factors may hinder the solidity of the gains coming from more balanced gender-based representation in the parliament (Goetz 1998; Goetz and Hassim 2003).

4. These associations were particularly evident in Swaziland and Mali.

5. "Goal 5: Achieve gender equality and empower all women and girls" (https://www.un.org/ sustainabledevelopment/gender-equality/).

6. World Bank, "TCdata36o: Global Gender Gap Political Empowerment Subindex" (https:// tcdata3 6 o.worldbank.org/indicators $/ 846 \mathrm{~d} 20$ f 8 ? country $=$ BRA $\&$ indicator $=2796 \mathrm{I} \& v i z=$ line chart\&years $=2006,2018)$. 
7. Note that there were 55I observations coded as "don't know." We recoded these as missing. Analyses recoding these as o instead of missing give essentially identical results and are available on request.

8. Any multilingualism implied by this measure should be interpreted with caution. Respondents can choose which language to respond in, and several may speak English, French, and/or Arabic but pick only one.

9. We do not include GDP per capita as a country-level control because a closely-related variable, gross national income (GNI) per capita, is one of the three components of the HDI. Results are robust to the substitution of the HDI by its three individual components and are also robust to use of GDP per capita instead of GNI per capita.

Io. As the AfroBarometer does not directly contain information on types of mobile devices (e.g., smartphone or simple feature phones) or specific types of digital use, we had originally included in our models some complementary indicators on gender gaps in Facebook use on different types of mobile devices in the country as an aggregate-level proxy for contextual features of digital connectivity. These data, computed as female-to-male ratios of Facebook users on different device types and derived from the Digital Gender Gaps project (https://www.digitalgendergaps.org) leverage data from the Facebook marketing application programming interface. But the models suggest that none of these country-level variables is a significant predictor of attitudes (thus not improving model performance), so we eventually decided to exclude them. The weak explanatory power of these country-level variables might suggest that the mobile-phone variable already captures the direct, individual-level effects of mobile connectivity and that contextual features matter less. It may also suggest that Facebook users only capture a selective subset of mobile users.

II. We acknowledge, though, that mobile-phone-network coverage could be correlated with other contextual factors (e.g., economic development and state infrastructure).

I2. We decided to include mobile-phone use (rather than ownership) as our predictor for the main analyses reported in the text because the measure more closely aligns with the ideas of improved access to information and more extensive communication theorized above. Also, mobile-phone ownership is more likely to suffer from endogeneity concerns, being more closely tied to socioeconomic status and personal economic/financial well-being.

\section{REFERENCES}

Abreu Lopes, Claudia, and Sharath Srinivasan. 2014. "Africa's Voices: Using Mobile Phones and Radio to Foster Mediated Public Discussion and to Gather Public Opinions in Africa." Working Paper 9, Centre of Governance and Human Rights, University of Cambridge.

Abubakar, Naima Hafiz, and Salihu Ibrahim Dasuki. 2018. "Empowerment in Their Hands: Use of WhatsApp by Women in Nigeria." Gender, Technology, and Development 22(2):164-83.

Aker, Jenny C. 2010. "Information from Markets Near and Far: Mobile Phones and Agricultural Markets in Niger." American Economic Journal: Applied Economics 2(3):46-59.

Aker, Jenny C., Christopher Ksoll, and Travis J. Lybbert. 2012. "Can Mobile Phones Improve Learning? Evidence from a Field Experiment in Niger." American Economic Journal: Applied Economics 4(4):94-I20.

Aker, Jenny C., and Isaac M. Mbiti. 2oro. "Mobile Phones and Economic Development in Africa." Journal of Economic Perspectives 24(3):207-32.

Angrist, Joshua D., and Jörn-Steffen Pischke. 2008. Mostly Harmless Econometrics: An Empiricist's Companion. Princeton University Press.

Banerjee, Abhijit, Eliana La Ferrara, and Victor Orozco. 2019. "Entertainment, Education, and Attitudes toward Domestic Violence." AEA Papers and Proceedings I09:133-37.

Beaman, Lori, Esther Duflo, Rohini Pande, and Petia Topalova. 2012. "Female Leadership Raises Aspirations and Educational Attainment for Girls: A Policy Experiment in India." Science $335(6068): 582-86$. 
Billari, Francesco C., Valentina Rotondi, and Jenny Trinitapoli. 2020. "Mobile Phones, Digital Inequality, and Fertility: Longitudinal Evidence from Malawi." Demographic Research 42(37): I057-96.

Blumenstock, Joshua, and Nathan Eagle. 2010. "Mobile Divides: Gender, Socioeconomic Status, and Mobile Phone Use in Rwanda." In Proceedings of the 4th ACM/IEEE International Conference on Information and Communication Technologies and Development, I-IO.

Bongaarts, John, and Susan Cotts Watkins. 1996. "Social Interactions and Contemporary Fertility Transitions." Population and Development Review 22(4):639-82.

Bruni, Luigino, and Luca Stanca. 2006. "Income Aspirations, Television and Happiness: Evidence from the World Values Survey." Kyklos 59(2):209-25.

Bursztyn, Leonardo, and Davide Cantoni. 2016. "A Tear in the Iron Curtain: The Impact of Western Television on Consumption Behavior." Review of Economics and Statistics 98(I):25-4I.

Charles, Maria. 2020. "Gender Attitudes in Africa: Liberal Egalitarianism across 34 Countries." Social Forces 99(I):86-I25.

Chatterjee, Karishma, and Vijayan K. Pillai. 2018. "Media Effects on Gender Child Preference in India." Journal of Research in Gender Studies 8(I):Io8-32.

Chong, Alberto, and Eliana La Ferrara. 2009. "Television and Divorce: Evidence from Brazilian Novelas." Journal of the European Economic Association 7(2-3):458-68.

DellaVigna, Stefano, and Ethan Kaplan. 2007. "The Fox News Effect: Media Bias and Voting." Quarterly Journal of Economics I22(3):I187-I234.

Dobashi, S. 2005. "The Gendered Use of Keitai in Domestic Contexts." In Personal, Portable, Pedestrian: Mobile Phones in Japanese Life, edited by M. Ito and D. Okabe, 219-36. MIT Press.

Donner, Jonathan. 2006. "The Use of Mobile Phones by Microentrepreneurs in Kigali, Rwanda: Changes to Social and Business Networks." Information Technologies and International Development 3(2):3-19.

Durante, Ruben, Paolo Pinotti, and Andrea Tesei. 2019. "The Political Legacy of Entertainment TV." American Economic Review 109(7):2497-2530.

Enikolopov, Ruben, Maria Petrova, and Ekaterina Zhuravskaya. 20II. "Media and Political Persuasion: Evidence from Russia." American Economic Review Ior(7):3253-85.

Fatehkia, Masoomali, Ridhi Kashyap, and Ingmar Weber. 2018. "Using Facebook Ad Data to Track the Global Digital Gender Gap." World Development 107:189-209.

Forsyth, Selina, and Kaitlin P. Ward. 2021. "Media Use and Men's Approval of Intimate Partner Violence in Honduras." Journal of Interpersonal Violence, https://doi.org/Io.II77/ o886260521993926.

Frank, David John, Tara Hardinge, and Kassia Wosick-Correa. 2009. "The Global Dimensions of Rape-Law Reform: A Cross-National Study of Policy Outcomes." American Sociological Review 74(2):272-90.

Frissen, Valerie. 2007. "Gender is Calling: Some Reflections on the Past, Present and Future Uses of the Telephone." Chap. 3 in The Gender-Technology Relation: Contemporary Research and Literature, edited by Keith Grint and Rosalind Gill. London: Taylor \& Francis.

Geser, Hans. 2004. "Towards a Sociological Theory of the Mobile Phone." In Sociology in Switzerland: Sociology of the Mobile Phone. Zurich: Online Publications.

Glas, Saskia, Niels Spierings, Marcel Lubbers, and Peer Scheepers. 2019. "How Polities Shape Support for Gender Equality and Religiosity's Impact in Arab Countries." European Sociological Review 35(3):299-315.

Goetz, Anne Marie. 1998. Women in Politics \& Gender Equity in Policy: South Africa \& Uganda. Taylor \& Francis.

Goetz, Anne Marie, and Shireen Hassim. 2003. No Shortcuts to Power: African Women in Politics and Policy Making. London: Zed Books. 
Gottlieb, Jessica, Guy Grossman, and Amanda Lea Robinson. 2018. "Do Men and Women Have Different Policy Preferences in Africa? Determinants and Implications of Gender Gaps in Policy Prioritization." British Journal of Political Science 48(3):6II-36.

Gray, Jonathan. 20II. "Mobility through Piracy, or How Steven Seagal Got to Malawi." Popular Communication 9(2):99-II3.

Gray, Jonathan. 20I4. "Scales of Cultural Influence: Malawian Consumption of Foreign Media." Media, Culture \& Society 36(7):982-97.

Green, Nicola. 2002. "On the Move: Technology, Mobility, and the Mediation of Social Time and Space." Information Society: An International Journal 18(4):28I-92.

GSMA. 2010. "Women and Mobile—a Global Opportunity: A Study on the Mobile Phone Gender Gap in Low- and Middle-Income Countries" (https://www.gsma.com/mobilefordevelopment/ wp-content/uploads/20I3/oI/GSMA_Women_and_Mobile-A_Global_Opportunity.pdf).

GSMA. 2020. "Mobile Connectivity 2020: Sub-Saharan Africa Factsheet" (https://www.gsma. $\mathrm{com} / \mathrm{r} / \mathrm{wp}$-content/uploads/2020/09/Mobile-Internet-Connectivity-SSA-Fact-Sheet.pdf).

Hendi, Arun. 20I7. "Globalization and Contemporary Fertility Convergence." Social Forces 96(I): $215-38$.

Hyll, Walter, and Lutz Schneider. 2013. "The Causal Effect of Watching TV on Material Aspirations: Evidence from the Valley of the Innocent." Journal of Economic Behavior \& Organization 86:37-51.

Inglehart, Ronald, and Pippa Norris. 2003. Rising Tide: Gender Equality and Cultural Change around the World. Cambridge University Press.

Jack, William, and Tavneet Suri. 2014. "Risk Sharing and Transactions Costs: Evidence from Kenya's Mobile Money Revolution." American Economic Review I04(I):I83-223.

Jensen, Robert. 2007. "The Digital Provide: Information (Technology), Market Performance, and Welfare in the South Indian Fisheries Sector." Quarterly Journal of Economics I22(3):879-924.

Jensen, Robert, and Emily Oster. 2009. "The Power of TV: Cable Television and Women's Status in India." Quarterly Journal of Economics I24(3):I057-94.

Johnson-Hanks, Jennifer A., S. Philip Morgan, Christine A. Bachrach, and Hans-Peter Kohler. 201 I. Understanding Family Change and Variation: Toward a Theory of Conjunctural Action. Springer.

Kearney, Melissa S., and Phillip B. Levine. 2015. "Media Influences on Social Outcomes: The Impact of MTV's I6 and Pregnant on Teen Childbearing." American Economic Review I05(I2): 3597-3632.

Knodel, John, and Etienne van de Walle. 1979. "Lessons from the Past: Policy Implications of Historical Fertility Studies." Population and Development Review 5(2):217-45.

La Ferrara, Eliana, Alberto Chong, and Suzanne Duryea. 2012. "Soap Operas and Fertility: Evidence from Brazil." American Economic Journal: Applied Economics 4(4):I-3I.

Lawoko, Stephen. 2006. "Factors Associated with Attitudes toward Intimate Partner Violence: A Study of Women in Zambia." Violence and Victims 2I(5):645-56.

Lee, Dayoung. 2009. The Impact of Mobile Phones on the Status of Women in India. Unpublished dissertation, Department of Economics, Stanford University (http://citeseerx.ist.psu.edu/ viewdoc/download?doi $=$ Io.I.I.647.792\& $\mathrm{rep}=$ repi \&type $=$ pdf).

Madianou, Mirca, and Daniel Miller. 20II. "Mobile Phone Parenting: Reconfiguring Relationships between Filipina Migrant Mothers and Their Left-Behind Children." New Media \& Society I3 (3): 457-70.

Meyer, John W. 20I0. "World Society, Institutional Theories, and the Actor." Annual Review of Sociology 36:I-20.

Meyer, John W., John Boli, George M. Thomas, and Francisco O. Ramirez. 1997. "World Society and the Nation-State." American Journal of Sociology IO3(I):I44-8I.

Montgomery, Mark R., and John B. Casterline. 1996. "Social Learning, Social Influence, and New Models of Fertility." Population and Development Review 22:15I-75.

Nelson, Barbara J., and Najma Chowdhury, eds. 1994. Women and Politics Worldwide. Yale University Press. 
Nyemba-Mudenda, Mphatso, and Wallace Chigona. 2018. "mHealth Outcomes for Pregnant Mothers in Malawi: A Capability Perspective." Information Technology for Development 24(2):245-78.

Okenwa-Emegwa, Leah, Stephen Lawoko, and Bjarne Jansson. 2016. "Attitudes toward Physical Intimate Partner Violence against Women in Nigeria.” Sage Open 6(4):2158244016667993.

Olken, Benjamin A. 2009. "Do Television and Radio Destroy Social Capital? Evidence from Indonesian Villages." American Economic Journal: Applied Economics I(4):I-33.

Paxton, Pamela, and Sheri Kunovich. 2003. "Women's Political Representation: The Importance of Ideology." Social Forces 82(I):87-II3.

Pesando, Luca Maria. Forthcoming. "Safer If Connected? Mobile Technology and Intimate Partner Violence." Demography.

Pesando, Luca Maria, and Valentina Rotondi. 2020. "Mobile Technology and Gender Equality." In Gender Equality, edited by W. Leal Filho, A. Azul, L. Brandli, A. Lange Salvia, and T. Wall. (A volume of Encyclopedia of the UN Sustainable Development Goals.) Cham: Springer.

Pew Research Center. 2015. "Cell Phones in Africa: Communication Lifeline." Global Attitudes \& Trends.

Pierotti, Rachael S. 2013. "Increasing Rejection of Intimate Partner Violence: Evidence of Global Cultural Diffusion." American Sociological Review 78(2):240-65.

Price, Anne. 20I4. "Differential Support for Women in Higher Education and Politics CrossNationally." Comparative Sociology I3(3):346-82.

Rakow, Lana. 1992. Gender on the Line: Women, the Telephone, and Community Life. University of Illinois Press.

Reynolds, Andrew. 1999. "Women in the Legislatures and Executives of the World: Knocking at the Highest Glass Ceiling.” World Politics 5I(4):547-72.

Rotondi, Valentina, Ridhi Kashyap, Luca Maria Pesando, Simone Spinelli, and Francesco C. Billari. 2020. "Leveraging Mobile Phones to Attain Sustainable Development." Proceedings of the National Academy of the Sciences II7(24):I34I3-20.

Rule, Wilma, and Joseph Francis Zimmerman, eds. 1994. Electoral Systems in Comparative Perspective: Their Impact on Women and Minorities. Greenwood.

Suri, Tavneet, and William Jack. 2016. "The Long-Run Poverty and Gender Impacts of Mobile Money.” Science 354(6317):1288-92.

Swiss, Liam, Kathleen M. Fallon, and Giovani Burgos. 2012. "Does Critical Mass Matter? Women's Political Representation and Child Health in Developing Countries." Social Forces 9I(2):53I-58.

Talbot, David. 2008. "Upwardly Mobile." MIT Technology Review, October 20 (https://www. technologyreview.com/2008/10/20/33244/upwardly-mobile/).

Tripp, Aili Mari, and Alice Kang. 2008. "The Global Impact of Quotas: On the Fast Track to Increased Female Legislative Representation." Comparative Political Studies 4I(3):338-6I.

Uthman, Olalekan A., Stephen Lawoko, and Tahereh Moradi. 2009. "Factors Associated with Attitudes towards Intimate Partner Violence against Women: A Comparative Analysis of I7 Sub-Saharan Countries." BMC International Health and Human Rights 9(I):I-I5.

Ward, L. Monique. 2016. "Media and Sexualization: State of Empirical Research, I995-2015." Journal of Sex Research 53(4-5):560-77.

Waverman, Leonard, Meloria Meschi, and Melvyn Fuss. 2005. "The Impact of Telecoms on Economic Growth in Developing Countries." Vodafone Policy Paper Series 2(3):I0-24.

Wei, Ran, and Ven-Hwei Lo. 2006. "Staying Connected while On the Move: Cell Phone Use and Social Connectedness." New Media \& Society 8(I):53-72.

Wellman, Barry. 1979. "The Community Question: The Intimate Networks of East Yorkers." American Journal of Sociology 84(5):I2OI-3I.

Westoff, Charles F., and Dawn A. Koffman. 20II. "The Association of Television and Radio with Reproductive Behavior." Population and Development Review 37(4):749-59.

Zayani, Mohamed. 2015. Networked Publics and Digital Contention: The Politics of Everyday Life in Tunisia. Oxford University Press. 
APPENDIX

TABLE A1. Associations between mobile-phone ownership and attitudes towards women in politics

\begin{tabular}{|c|c|c|c|}
\hline & $\begin{array}{c}\text { (1) } \\
\text { Overall } \\
\text { b/se }\end{array}$ & $\begin{array}{c}\text { (2) } \\
\text { Women } \\
\text { b/se }\end{array}$ & $\begin{array}{l}\text { (3) } \\
\text { Men } \\
\text { b/se }\end{array}$ \\
\hline \multirow[t]{2}{*}{ Own mobile phone } & $0.056^{\star \star \star}$ & $0.036^{\star \star \star}$ & 0.009 \\
\hline & $(0.008)$ & $(0.009)$ & $(0.012)$ \\
\hline \multirow[t]{2}{*}{ Age } & $0.002^{\star \star}$ & 0.002 & 0.002 \\
\hline & $(0.001)$ & $(0.001)$ & $(0.001)$ \\
\hline \multirow[t]{2}{*}{ Age squared } & -0.000 & $-0.000^{\star}$ & -0.000 \\
\hline & $(0.000)$ & $(0.000)$ & $(0.000)$ \\
\hline \multirow{2}{*}{ Personal econ. conditions $=$ bad } & $-0.015^{\star \star}$ & -0.009 & $-0.021^{\star \star}$ \\
\hline & $(0.007)$ & $(0.009)$ & $(0.010)$ \\
\hline \multirow[t]{2}{*}{ Personal econ. conditions $=$ neither good nor bad } & $-0.013^{\star}$ & -0.008 & $-0.021^{\star}$ \\
\hline & $(0.007)$ & $(0.010)$ & $(0.011)$ \\
\hline \multirow[t]{2}{*}{ Personal econ. conditions $=$ good } & -0.003 & -0.009 & 0.003 \\
\hline & $(0.007)$ & $(0.009)$ & $(0.010)$ \\
\hline \multirow{2}{*}{ Personal econ. conditions = very good } & $-0.024^{\star \star}$ & $-0.039^{\star \star}$ & -0.010 \\
\hline & $(0.012)$ & $(0.015)$ & $(0.018)$ \\
\hline \multirow[t]{2}{*}{ Own radio } & $0.016^{\star \star \star}$ & $0.013^{\star}$ & $0.015^{\star}$ \\
\hline & $(0.005)$ & $(0.007)$ & $(0.009)$ \\
\hline \multirow[t]{2}{*}{ Own tv } & -0.001 & -0.004 & 0.002 \\
\hline & $(0.006)$ & $(0.008)$ & $(0.009)$ \\
\hline \multirow[t]{2}{*}{ Employed (waged job) } & $0.020^{\star}$ & $0.026^{\star}$ & 0.007 \\
\hline & $(0.011)$ & $(0.013)$ & $(0.017)$ \\
\hline \multirow[t]{2}{*}{ Male } & $-0.107^{\star \star \star}$ & & \\
\hline & $(0.010)$ & & \\
\hline \multirow[t]{2}{*}{ Ow mobile phone*employed } & $-0.031^{\star \star \star}$ & -0.021 & -0.023 \\
\hline & $(0.012)$ & $(0.015)$ & $(0.019)$ \\
\hline \multirow[t]{2}{*}{ Ow mobile phone ${ }^{\star}$ gender } & $-0.060^{\star \star \star}$ & & \\
\hline & $(0.011)$ & & \\
\hline \multirow[t]{2}{*}{ Primary education } & $0.018^{\star \star}$ & 0.012 & $0.025^{\star \star}$ \\
\hline & $(0.007)$ & $(0.009)$ & $(0.011)$ \\
\hline
\end{tabular}


TABLE A1. Associations between mobile-phone ownership and attitudes towards women in politics (continued)

\begin{tabular}{lccc}
\hline & $\begin{array}{c}(1) \\
\text { Overall } \\
b / s e\end{array}$ & $\begin{array}{c}\text { Women } \\
\text { b/se }\end{array}$ & $\begin{array}{c}\text { Men } \\
b / s e\end{array}$ \\
\hline Secondary education & $0.064^{\star \star \star}$ & $0.045^{\star \star \star}$ & $0.085^{\star \star \star}$ \\
& $(0.008)$ & $(0.010)$ & $(0.012)$ \\
Tertiary education & $0.108^{\star \star \star}$ & $0.076^{\star \star \star}$ & $0.137^{\star \star \star}$ \\
Rural & $(0.010)$ & $(0.013)$ & $(0.014)$ \\
N. adults in HH & $-0.020^{\star \star \star}$ & $-0.023^{\star \star \star}$ & $-0.016^{\star \star}$ \\
HDI & $(0.005)$ & $(0.007)$ & $(0.008)$ \\
& $-0.003^{\star \star \star}$ & $-0.002^{\star}$ & $-0.004^{\star \star \star}$ \\
Political empowerment GG subindex & $(0.001)$ & $(0.001)$ & $(0.001)$ \\
& 0.111 & 0.296 & -0.089 \\
\hline Observations & $(0.210)$ & $(0.192)$ & $(0.241)$ \\
\hline
\end{tabular}

Note: Marginal effects probit table. ${ }^{\star} p<0.10,{ }^{\star \star} p<0.05,{ }^{\star \star \star} p<0.01$. Reference category for education: No education; Reference category for personal economic conditions: Very bad.

TABLE A2. Associations between mobile-phone daily use and attitudes towards women in politics - Marginal effects simple probit table

\begin{tabular}{lcccc}
\hline & \multicolumn{2}{c}{ Women have same chance of being elected as men } \\
\cline { 2 - 5 } & $\begin{array}{c}\text { Women } \\
\mathrm{b} / \mathrm{se}\end{array}$ & $\begin{array}{c}\text { Men } \\
\mathrm{b} / \mathrm{se}\end{array}$ & $\begin{array}{c}\text { Overall } \\
\mathrm{b} / \mathrm{se}\end{array}$ & $\begin{array}{c}\text { Overall } \\
\mathrm{b} / \mathrm{se}\end{array}$ \\
\hline Use mobile phone daily $(\mathrm{d})$ & $0.053^{\star \star \star}$ & 0.031 & $0.066^{\star \star \star}$ & $0.064^{\star \star \star}$ \\
Age & $(0.013)$ & $(0.019)$ & $(0.014)$ & $(0.014)$ \\
Age squared & 0.001 & 0.001 & 0.001 & 0.001 \\
Personal econ. conditions $=$ bad & $(0.002)$ & $(0.002)$ & $(0.001)$ & $(0.001)$ \\
& -0.000 & 0.000 & 0.000 & -0.000 \\
& $(0.000)$ & $(0.000)$ & $(0.000)$ & $(0.000)$ \\
& -0.007 & -0.016 & -0.009 & -0.012 \\
& $(0.014)$ & $(0.018)$ & $(0.012)$ & $(0.014)$ \\
\hline
\end{tabular}


TABLE A2. Associations between mobile-phone daily use and attitudes towards women in politics - Marginal effects simple probit table (continued)

\begin{tabular}{|c|c|c|c|c|}
\hline & \multicolumn{4}{|c|}{ Women have same chance of being elected as men } \\
\hline & $\begin{array}{c}\text { Women } \\
\text { b/se }\end{array}$ & $\begin{array}{l}\text { Men } \\
\mathrm{b} / \mathrm{se}\end{array}$ & $\begin{array}{c}\text { Overall } \\
\text { b/se }\end{array}$ & $\begin{array}{c}\text { Overall } \\
\text { b/se }\end{array}$ \\
\hline \multirow[t]{2}{*}{ Personal econ. conditions $=$ very bad } & -0.007 & -0.017 & -0.013 & -0.012 \\
\hline & $(0.016)$ & $(0.021)$ & $(0.018)$ & $(0.017)$ \\
\hline \multirow[t]{2}{*}{ Personal econ. conditions $=$ good } & -0.017 & 0.000 & -0.015 & -0.009 \\
\hline & $(0.018)$ & $(0.024)$ & $(0.019)$ & $(0.020)$ \\
\hline \multirow[t]{2}{*}{ Personal econ. conditions $=$ very good } & $-0.084^{\star \star}$ & -0.035 & $-0.058^{\star \star}$ & $-0.060^{\star}$ \\
\hline & $(0.036)$ & $(0.031)$ & $(0.029)$ & $(0.031)$ \\
\hline \multirow[t]{2}{*}{ Own radio } & 0.006 & $0.028^{\star}$ & 0.012 & 0.018 \\
\hline & $(0.013)$ & $(0.016)$ & $(0.013)$ & $(0.013)$ \\
\hline \multirow[t]{2}{*}{ Own tv } & -0.028 & -0.017 & -0.026 & -0.024 \\
\hline & $(0.018)$ & $(0.021)$ & $(0.023)$ & $(0.018)$ \\
\hline \multirow[t]{2}{*}{ Employed (waged job) } & $0.038^{\star \star}$ & -0.016 & 0.015 & 0.013 \\
\hline & $(0.018)$ & $(0.032)$ & $(0.018)$ & $(0.019)$ \\
\hline \multirow[t]{2}{*}{ Primary education } & 0.023 & $0.043^{\star \star}$ & $0.051^{\star \star \star}$ & 0.033 \\
\hline & $(0.023)$ & $(0.021)$ & $(0.020)$ & $(0.021)$ \\
\hline \multirow[t]{2}{*}{ Secondary education } & $0.060^{\star}$ & $0.111^{\star \star \star}$ & $0.104^{\star \star \star}$ & $0.087^{\star \star \star}$ \\
\hline & $(0.033)$ & $(0.029)$ & $(0.024)$ & $(0.029)$ \\
\hline \multirow[t]{2}{*}{ Tertiary education } & $0.066^{\star \star}$ & $0.136^{\star \star \star}$ & $0.120^{\star \star \star}$ & $0.104^{\star \star \star}$ \\
\hline & $(0.030)$ & $(0.028)$ & $(0.023)$ & $(0.028)$ \\
\hline \multirow[t]{2}{*}{ Rural } & -0.019 & -0.007 & $-0.020^{\star}$ & -0.013 \\
\hline & $(0.013)$ & $(0.012)$ & $(0.012)$ & $(0.012)$ \\
\hline \multirow[t]{2}{*}{$\mathrm{N}$. adults in $\mathrm{HH}$} & $-0.006^{\star}$ & $-0.011^{\star \star \star}$ & $-0.008^{\star \star \star}$ & $-0.008^{\star \star \star}$ \\
\hline & $(0.003)$ & $(0.003)$ & $(0.003)$ & $(0.003)$ \\
\hline \multirow[t]{2}{*}{ Mob. phone employed } & -0.022 & -0.010 & $-0.027^{\star}$ & -0.023 \\
\hline & $(0.019)$ & $(0.027)$ & $(0.015)$ & $(0.017)$ \\
\hline \multirow[t]{2}{*}{$\mathrm{HDI}$} & 0.150 & -0.273 & & -0.069 \\
\hline & $(0.266)$ & $(0.304)$ & & $(0.284)$ \\
\hline \multirow[t]{2}{*}{ Political empowerment GG subindex } & 0.224 & 0.268 & & 0.246 \\
\hline & $(0.174)$ & $(0.184)$ & & $(0.172)$ \\
\hline
\end{tabular}


TABLE A2. Associations between mobile-phone daily use and attitudes towards women in politics - Marginal effects simple probit table (continued)

\begin{tabular}{|c|c|c|c|c|}
\hline & \multicolumn{4}{|c|}{ Women have same chance of being elected as men } \\
\hline & $\begin{array}{c}\text { Women } \\
\text { b/se }\end{array}$ & $\begin{array}{l}\text { Men } \\
\text { b/se }\end{array}$ & $\begin{array}{c}\text { Overall } \\
\text { b/se }\end{array}$ & $\begin{array}{c}\text { Overall } \\
\text { b/se }\end{array}$ \\
\hline \multirow[t]{2}{*}{ Male } & & & $-0.130^{\star \star \star}$ & $-0.139^{\star \star \star}$ \\
\hline & & & $(0.018)$ & $(0.020)$ \\
\hline \multirow[t]{2}{*}{ Mob. phone ${ }^{\star}$ male } & & & $-0.031^{\star \star}$ & \\
\hline & & & $(0.015)$ & \\
\hline \multirow[t]{2}{*}{ Mob. phone ${ }^{\star}$ male } & & & & $-0.034^{\star \star}$ \\
\hline & & & & $(0.017)$ \\
\hline $\mathrm{N}$ & 20,644 & 20,508 & 49,224 & 41,152 \\
\hline
\end{tabular}

Note: Marginal effects probit table. ${ }^{\star} p<0.10,{ }^{\star \star} p<0.05,{ }^{\star \star \star} p<0.01$. Reference category for education: No education; Reference category for personal economic conditions: Very bad.

TABLE A3. Associations between mobile-phone daily use and attitudes towards women in politics - Linear Probability Model (LPM)

\begin{tabular}{lcccc}
\hline & $(1)$ & $(2)$ & $(3)$ & $(4)$ \\
\cline { 2 - 5 } & Women have same chance of being elected as men \\
\cline { 2 - 5 } & Women & Men & Overall & Overall \\
& $b / \mathrm{se}$ & $\mathrm{b} / \mathrm{se}$ & $\mathrm{b} / \mathrm{se}$ & $\mathrm{b} / \mathrm{se}$ \\
\hline Use mobile phone daily $(\mathrm{d})$ & $0.054^{\star \star \star}$ & 0.030 & $0.058^{\star \star \star}$ & $0.056^{\star \star \star}$ \\
Age & $(0.014)$ & $(0.019)$ & $(0.013)$ & $(0.013)$ \\
Age squared & 0.001 & 0.001 & 0.001 & 0.001 \\
Personal econ. conditions $=$ bad & $(0.002)$ & $(0.002)$ & $(0.001)$ & $(0.001)$ \\
& -0.000 & 0.000 & 0.000 & -0.000 \\
Personal econ. conditions $=$ good & $(0.000)$ & $(0.000)$ & $(0.000)$ & $(0.000)$ \\
& -0.007 & -0.015 & -0.009 & -0.012 \\
& $(0.014)$ & $(0.018)$ & $(0.012)$ & $(0.014)$ \\
& -0.007 & -0.017 & -0.013 & -0.012 \\
& $(0.016)$ & $(0.021)$ & $(0.018)$ & $(0.017)$ \\
& -0.017 & -0.000 & -0.015 & -0.009 \\
& $(0.018)$ & $(0.024)$ & $(0.019)$ & $(0.019)$ \\
\hline
\end{tabular}


TABLE A3. Associations between mobile-phone daily use and attitudes towards women in politics - Linear Probability Model (LPM) (continued)

\begin{tabular}{|c|c|c|c|c|}
\hline & (1) & $(2)$ & (3) & (4) \\
\hline & \multicolumn{4}{|c|}{ Women have same chance of being elected as men } \\
\hline & $\begin{array}{c}\text { Women } \\
\text { b/se }\end{array}$ & $\begin{array}{l}\text { Men } \\
\text { b/se }\end{array}$ & $\begin{array}{l}\text { Overall } \\
\text { b/se }\end{array}$ & $\begin{array}{c}\text { Overall } \\
\text { b/se }\end{array}$ \\
\hline \multirow[t]{2}{*}{ Personal econ. conditions $=$ very good } & $-0.081^{\star \star}$ & -0.034 & $-0.055^{\star}$ & $-0.057^{\star}$ \\
\hline & $(0.035)$ & $(0.031)$ & $(0.027)$ & $(0.030)$ \\
\hline \multirow[t]{2}{*}{ Own radio } & 0.007 & $0.027^{\star}$ & 0.012 & 0.017 \\
\hline & $(0.013)$ & $(0.016)$ & $(0.012)$ & $(0.013)$ \\
\hline \multirow[t]{2}{*}{ Own tv } & -0.028 & -0.017 & -0.026 & -0.024 \\
\hline & $(0.018)$ & $(0.020)$ & $(0.023)$ & $(0.018)$ \\
\hline \multirow[t]{2}{*}{ Employed (waged job) } & $0.041^{\star \star}$ & -0.017 & 0.015 & 0.013 \\
\hline & $(0.019)$ & $(0.032)$ & $(0.018)$ & $(0.019)$ \\
\hline \multirow[t]{2}{*}{ Primary education } & 0.026 & $0.044^{\star \star}$ & $0.054^{\star \star}$ & 0.035 \\
\hline & $(0.026)$ & $(0.021)$ & $(0.021)$ & $(0.022)$ \\
\hline \multirow[t]{2}{*}{ Secondary education } & $0.064^{\star}$ & $0.113^{\star \star \star}$ & $0.107^{\star \star \star}$ & $0.089^{\star \star \star}$ \\
\hline & $(0.036)$ & $(0.030)$ & $(0.026)$ & $(0.031)$ \\
\hline \multirow[t]{2}{*}{ Tertiary education } & $0.071^{\star}$ & $0.141^{\star \star \star}$ & $0.128^{\star \star \star}$ & $0.110^{\star \star \star}$ \\
\hline & $(0.036)$ & $(0.031)$ & $(0.027)$ & $(0.031)$ \\
\hline \multirow[t]{2}{*}{ Rural } & -0.018 & -0.006 & -0.019 & -0.012 \\
\hline & $(0.012)$ & $(0.012)$ & $(0.011)$ & $(0.011)$ \\
\hline \multirow[t]{2}{*}{$\mathrm{N}$. adults in $\mathrm{HH}$} & $-0.006^{\star}$ & $-0.011^{\star \star \star}$ & $-0.009^{\star \star \star}$ & $-0.008^{\star \star}$ \\
\hline & $(0.003)$ & $(0.003)$ & $(0.003)$ & $(0.003)$ \\
\hline \multirow[t]{2}{*}{ Mob. phone*employed } & -0.026 & -0.010 & $-0.027^{\star}$ & -0.023 \\
\hline & $(0.019)$ & $(0.027)$ & $(0.016)$ & $(0.017)$ \\
\hline \multirow[t]{2}{*}{$\mathrm{HDI}$} & 0.143 & -0.271 & & -0.074 \\
\hline & $(0.258)$ & $(0.302)$ & & $(0.277)$ \\
\hline \multirow[t]{2}{*}{ Political empowerment GG subindex } & 0.217 & 0.263 & & 0.236 \\
\hline & $(0.165)$ & $(0.179)$ & & $(0.163)$ \\
\hline \multirow[t]{2}{*}{ Male } & & & $-0.135^{\star \star \star}$ & $-0.143^{\star \star \star}$ \\
\hline & & & $(0.018)$ & $(0.021)$ \\
\hline \multirow[t]{2}{*}{ Mob. phone*male } & & & -0.021 & \\
\hline & & & $(0.015)$ & \\
\hline
\end{tabular}


TABLE A3. Associations between mobile-phone daily use and attitudes towards women in politics - Linear Probability Model (LPM) (continued)

\begin{tabular}{|c|c|c|c|c|}
\hline & (1) & (2) & (3) & (4) \\
\hline & \multicolumn{4}{|c|}{ Women have same chance of being elected as men } \\
\hline & $\begin{array}{c}\text { Women } \\
\text { b/se }\end{array}$ & $\begin{array}{l}\text { Men } \\
b / s e\end{array}$ & $\begin{array}{c}\text { Overall } \\
\text { b/se }\end{array}$ & $\begin{array}{l}\text { Overall } \\
\text { b/se }\end{array}$ \\
\hline Mob. phone ${ }^{\star}$ male & & & & $\begin{array}{l}-0.024 \\
(0.017)\end{array}$ \\
\hline N. & 20,644 & 20,508 & 49,224 & 41,152 \\
\hline
\end{tabular}

Note: Linear Probability Model. Standard errors clustered at the country level. ${ }^{\star} p<0.10,{ }^{\star \star} p<0.05,{ }^{\star \star \star} p<0.01$. Reference category for education: No education; Reference category for personal economic conditions: Very bad.

TABLE A4. Associations between mobile-phone daily use and attitudes towards women in politics - Marginal effects simple probit table with country fixed effects

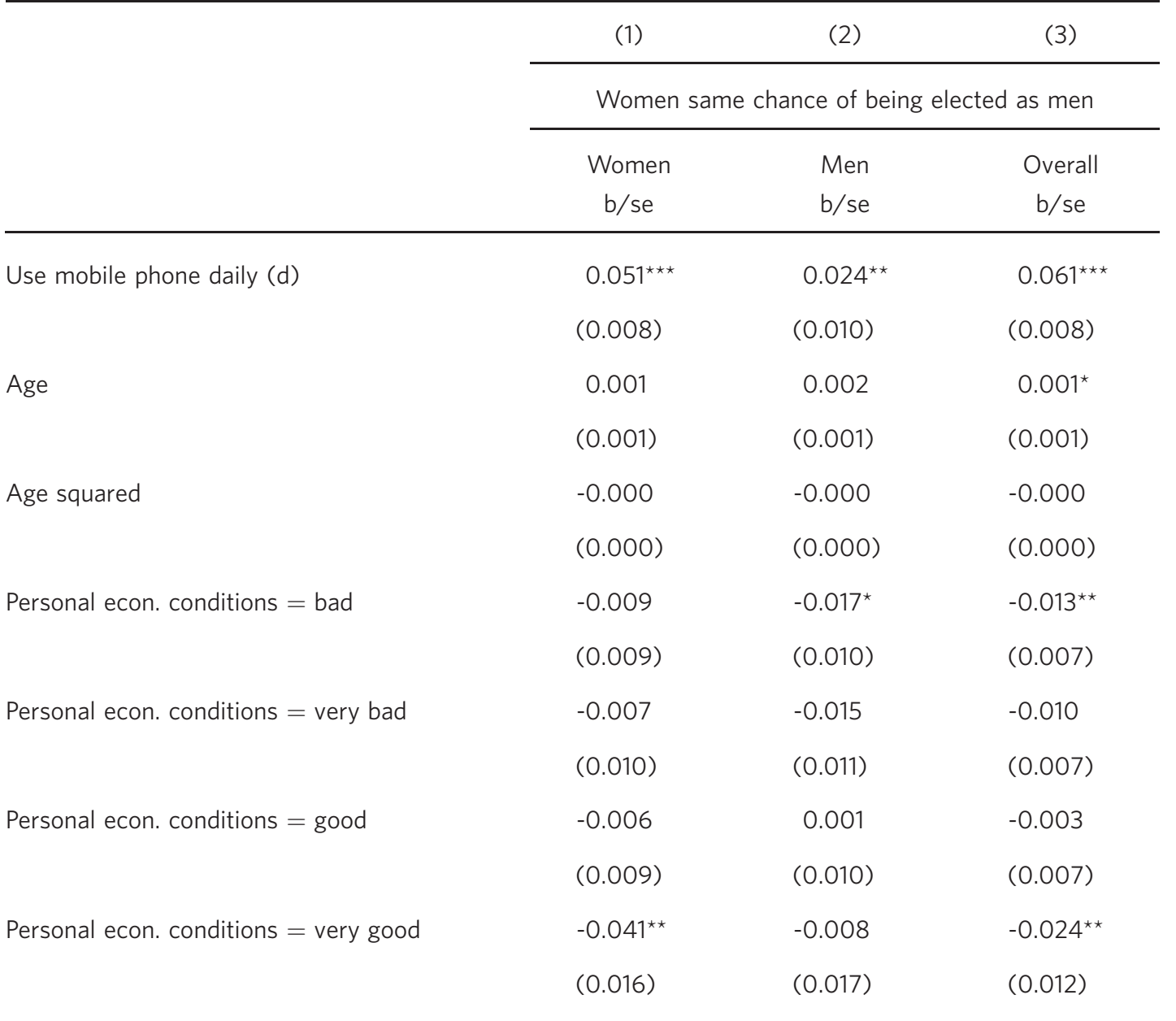


TABLE A4. Associations between mobile-phone daily use and attitudes towards women in politics - Marginal effects simple probit table with country fixed effects (continued)

\begin{tabular}{|c|c|c|c|}
\hline & (1) & (2) & (3) \\
\hline & \multicolumn{3}{|c|}{ Women same chance of being elected as men } \\
\hline & $\begin{array}{c}\text { Women } \\
\text { b/se }\end{array}$ & $\begin{array}{l}\text { Men } \\
\mathrm{b} / \mathrm{se}\end{array}$ & $\begin{array}{c}\text { Overall } \\
\text { b/se }\end{array}$ \\
\hline \multirow[t]{2}{*}{ Own radio } & 0.009 & $0.019^{\star \star}$ & $0.015^{\star \star \star}$ \\
\hline & $(0.007)$ & $(0.008)$ & $(0.005)$ \\
\hline \multirow[t]{2}{*}{ Own tv } & -0.007 & -0.000 & -0.005 \\
\hline & $(0.008)$ & $(0.009)$ & $(0.006)$ \\
\hline \multirow[t]{2}{*}{ Employed (waged job) } & $0.034^{\star \star \star}$ & 0.000 & $0.019^{\star \star}$ \\
\hline & $(0.011)$ & $(0.014)$ & $(0.009)$ \\
\hline \multirow[t]{2}{*}{ Primary education } & 0.009 & $0.025^{\star \star}$ & $0.017^{\star \star}$ \\
\hline & $(0.008)$ & $(0.011)$ & $(0.007)$ \\
\hline \multirow[t]{2}{*}{ Secondary education } & $0.044^{\star \star \star}$ & $0.083^{\star \star \star}$ & $0.063^{\star \star \star}$ \\
\hline & $(0.009)$ & $(0.011)$ & $(0.007)$ \\
\hline \multirow[t]{2}{*}{ Tertiary education } & $0.081^{\star \star \star}$ & $0.131^{\star \star \star}$ & $0.107^{\star \star \star}$ \\
\hline & $(0.010)$ & $(0.012)$ & $(0.008)$ \\
\hline \multirow[t]{2}{*}{ Rural } & $-0.019^{\star \star \star}$ & -0.012 & $-0.016^{\star \star \star}$ \\
\hline & $(0.007)$ & $(0.008)$ & $(0.005)$ \\
\hline \multirow[t]{2}{*}{$\mathrm{N}$. adults in $\mathrm{HH}$} & $-0.002^{\star}$ & $-0.003^{\star \star}$ & $-0.002^{\star \star \star}$ \\
\hline & $(0.001)$ & $(0.001)$ & $(0.001)$ \\
\hline \multirow[t]{2}{*}{ Mob. phone*employed } & $-0.035^{\star \star}$ & -0.015 & $-0.030^{\star \star \star}$ \\
\hline & $(0.014)$ & $(0.016)$ & $(0.011)$ \\
\hline \multirow[t]{2}{*}{ Male } & & & $-0.130^{\star \star \star}$ \\
\hline & & & $(0.008)$ \\
\hline \multirow[t]{2}{*}{ Mob. phone*male } & & & $-0.039^{\star \star \star}$ \\
\hline & & & $(0.010)$ \\
\hline Country FE & Yes & Yes & Yes \\
\hline N. & 24,659 & 24,565 & 49,224 \\
\hline
\end{tabular}

Note: Marginal effects probit table. ${ }^{\star} p<0.10,{ }^{\star \star} p<0.05,{ }^{\star \star \star} p<0.01$. Reference category for education: No education; Reference category for personal economic conditions: Very bad. 
TABLE A5. Mobile-phone daily usage/ownership and mobile coverage: first stage Instrumental Variable (IV) regression

\begin{tabular}{lcc}
\hline & $\begin{array}{c}(1) \\
\text { Use mobile phone daily } \\
b / s e\end{array}$ & Own mobile phone b/se \\
\hline Cell phone service in the PSU/EA & $0.285^{\star \star \star}$ & $0.254^{\star \star \star}$ \\
\hline $\mathrm{N}$. & $(0.034)$ & $(0.044)$ \\
\hline
\end{tabular}

Note: First stage regression. Standard errors clustered at country level. ${ }^{\star} p<0.10,{ }^{\star \star} p<0.05,{ }^{\star \star \star} p<0.01$

TABLE A6. Associations between mobile-phone ownership and attitudes towards women in politics - IV probit

\begin{tabular}{|c|c|c|c|}
\hline & $\begin{array}{c}(1) \\
\text { Overall } \\
\text { b/se }\end{array}$ & $\begin{array}{c}(2) \\
\text { Women } \\
\text { b/se }\end{array}$ & $\begin{array}{l}\text { (3) } \\
\text { Men } \\
\text { b/se }\end{array}$ \\
\hline \multirow[t]{2}{*}{ Own mobile phone (fitted values) } & 0.071 & $0.148^{\star \star}$ & -0.023 \\
\hline & $(0.075)$ & $(0.074)$ & $(0.101)$ \\
\hline \multirow[t]{2}{*}{ Own mobile phone*employed } & -0.010 & 0.005 & -0.026 \\
\hline & $(0.017)$ & $(0.019)$ & $(0.030)$ \\
\hline \multirow[t]{2}{*}{ Own mobile phone ${ }^{\star}$ male } & -0.013 & & \\
\hline & $(0.018)$ & & \\
\hline \multirow[t]{2}{*}{ Age } & 0.001 & 0.001 & 0.001 \\
\hline & $(0.001)$ & $(0.001)$ & $(0.001)$ \\
\hline \multirow[t]{2}{*}{ Age squared } & -0.000 & -0.000 & -0.000 \\
\hline & $(0.000)$ & $(0.000)$ & $(0.000)$ \\
\hline \multirow[t]{2}{*}{ Personal econ. conditions $=$ bad } & -0.006 & -0.005 & -0.007 \\
\hline & $(0.012)$ & $(0.012)$ & $(0.016)$ \\
\hline \multirow[t]{2}{*}{ Personal econ. conditions $=$ neither good nor bad } & -0.007 & -0.011 & -0.002 \\
\hline & $(0.018)$ & $(0.019)$ & $(0.021)$ \\
\hline \multirow[t]{2}{*}{ Personal econ. conditions $=$ good } & -0.008 & -0.015 & -0.001 \\
\hline & $(0.019)$ & $(0.019)$ & $(0.023)$ \\
\hline \multirow[t]{2}{*}{ Personal econ. conditions = very good } & $-0.054^{\star \star}$ & $-0.078^{\star \star}$ & -0.030 \\
\hline & $(0.027)$ & $(0.031)$ & $(0.028)$ \\
\hline
\end{tabular}


TABLE A6. Associations between mobile-phone ownership and attitudes towards women in politics - IV probit (continued)

\begin{tabular}{|c|c|c|c|}
\hline & $\begin{array}{c}\text { (1) } \\
\text { Overall } \\
\text { b/se }\end{array}$ & $\begin{array}{c}\text { (2) } \\
\text { Women } \\
\text { b/se }\end{array}$ & $\begin{array}{l}\text { (3) } \\
\text { Men } \\
\text { b/se }\end{array}$ \\
\hline \multirow[t]{2}{*}{ Own radio } & 0.016 & 0.011 & 0.021 \\
\hline & $(0.013)$ & $(0.013)$ & $(0.015)$ \\
\hline \multirow[t]{2}{*}{ Own tv } & -0.005 & -0.004 & -0.004 \\
\hline & $(0.020)$ & $(0.021)$ & $(0.023)$ \\
\hline \multirow[t]{2}{*}{ Employed (waged job) } & 0.008 & 0.023 & -0.004 \\
\hline & $(0.018)$ & $(0.020)$ & $(0.033)$ \\
\hline \multirow[t]{2}{*}{ Male } & $-0.134^{\star \star \star}$ & & \\
\hline & $(0.021)$ & & \\
\hline \multirow[t]{2}{*}{ Primary education } & $0.045^{\star \star}$ & 0.035 & $0.056^{\star \star \star}$ \\
\hline & $(0.019)$ & $(0.022)$ & $(0.018)$ \\
\hline \multirow[t]{2}{*}{ Secondary education } & $0.101^{\star \star \star}$ & $0.081^{\star \star \star}$ & $0.120^{\star \star \star}$ \\
\hline & $(0.023)$ & $(0.028)$ & $(0.023)$ \\
\hline \multirow[t]{2}{*}{ Tertiary education } & $0.126^{\star \star \star}$ & $0.101^{\star \star \star}$ & $0.149^{\star \star \star}$ \\
\hline & $(0.026)$ & $(0.031)$ & $(0.025)$ \\
\hline \multirow[t]{2}{*}{ Rural } & $-0.022^{\star}$ & $-0.027^{\star \star}$ & -0.016 \\
\hline & $(0.012)$ & $(0.013)$ & $(0.013)$ \\
\hline \multirow[t]{2}{*}{$\mathrm{N}$. adults in $\mathrm{HH}$} & $-0.008^{\star \star \star}$ & $-0.005^{\star}$ & $-0.011^{\star \star \star}$ \\
\hline & $(0.003)$ & $(0.003)$ & $(0.003)$ \\
\hline Observations & 48,332 & 24,235 & 24,097 \\
\hline
\end{tabular}

Note: Marginal effects probit table. ${ }^{\star} p<0.10,{ }^{\star \star} p<0.05,{ }^{\star \star \star} p<0.01$. Reference category for education: No education; Reference category for personal economic conditions: Very bad. 